\title{
Handheld Devices for Food Authentication and Their Applications: A Review
}

\author{
Judith Müller-Maatsch ${ }^{1}$ (D) and Saskia M. van Ruth ${ }^{1,2, *(D)}$ \\ 1 Wageningen Food Safety Research, Wageningen University and Research, P.O. Box 230, \\ 6700 EV Wageningen, The Netherlands; judith.mueller-maatsch@wur.nl \\ 2 Food Quality and Design, Wageningen University and Research, P.O. Box 17, \\ 6700 AA Wageningen, The Netherlands \\ * Correspondence: saskia.vanruth@wur.nl; Tel.: +31-317-480250
}

Citation: Müller-Maatsch, J.; van Ruth, S.M. Handheld Devices for Food Authentication and Their Applications: A Review. Foods 2021, 10, 2901. https://doi.org/10.3390/ foods10122901

Academic Editor: Jan Mei Soon

Received: 4 November 2021

Accepted: 21 November 2021

Published: 23 November 2021

Publisher's Note: MDPI stays neutral with regard to jurisdictional claims in published maps and institutional affiliations.

Copyright: (c) 2021 by the authors Licensee MDPI, Basel, Switzerland. This article is an open access article distributed under the terms and conditions of the Creative Commons Attribution (CC BY) license (https:// creativecommons.org/licenses/by/ $4.0 /)$.

\begin{abstract}
This review summarises miniaturised technologies, commercially available devices, and device applications for food authentication or measurement of features that could potentially be used for authentication. We first focus on the handheld technologies and their generic characteristics: (1) technology types available, (2) their design and mode of operation, and (3) data handling and output systems. Subsequently, applications are reviewed according to commodity type for products of animal and plant origin. The 150 applications of commercial, handheld devices involve a large variety of technologies, such as various types of spectroscopy, imaging, and sensor arrays. The majority of applications, $\sim 60 \%$, aim at food products of plant origin. The technologies are not specifically aimed at certain commodities or product features, and no single technology can be applied for authentication of all commodities. Nevertheless, many useful applications have been developed for many food commodities. However, the use of these applications in practice is still in its infancy. This is largely because for each single application, new spectral databases need to be built and maintained. Therefore, apart from developing applications, a focus on sharing and re-use of data and calibration transfers is pivotal to remove this bottleneck and to increase the implementation of these technologies in practice.
\end{abstract}

Keywords: food fraud; food integrity; on-site detection; portable devices

\section{Introduction}

Over the years, technologies have advanced rapidly and enabled more precise, more efficient, and faster checks of foods for integrity issues to ensure the quality, safety, and authenticity of foods in supply chains. Food authenticity "is about ensuring that food offered for sale or sold is of the nature, substance, and quality expected by the purchaser" $[1,2]$. Some food fraud cases have impacted on human health, like the addition of melamine to milk powders [3] or the counterfeiting of alcoholic beverages with technical alcohol [4]. Other frauds simply economically disadvantaged consumers, e.g., the passing on of refined olive oil as extra virgin olive oil [5]. When developing new means for food authentication, research has focused mostly on single food commodities, single fraud issues, and/or single technologies. Food authentication methods have traditionally concerned measurement of single markers or a small set of markers with comparison to set thresholds. Over the last two decades, more and more food authentication methods have focussed on analytical signatures, which are based on either known compounds (targeted-profiling) or unidentified features (untargeted-fingerprints) [6,7]. Most of these methods are based on spectrometric or spectroscopic analyses in combination with advanced statistical methods. At the same time, miniaturisation of technologies has allowed more and more use of analytical devices outside laboratory environments [8,9]. This includes noninvasive [10] and handheld, portable devices, some of which are coupled to or even integrated into smartphones [11]. 
Overviews of these technologies are useful for those that wish to select promising applications or to build further on them. Some studies have reviewed miniaturised applications in this area for particular products. For instance, methodologies/applications focusing on meat [12,13], dairy products [14], and honey [15] as well as plant foodstuffs [16] have been reviewed. These reviews include primarily evaluations of prototypes with a proof-of-concept approach, which are not (yet) operable on a large scale in practice. Despite the reviews mentioned above, technologies for food authentication on the intersection of handheld commercially available technologies and several food commodities have not been reviewed comprehensively till date.

Therefore, this review aims towards an overview of miniaturised technologies, commercially available devices, and applications for food authentication, or those that at least consider features that are relevant for food authenticity or the identity of foods. Firstly, the available handheld technologies are appraised by their generic characteristics: (1) the type of technologies available, (2) their design and mode of operation, and (3) data handling and output systems. Subsequently, applications of the various technologies are reviewed for food products of animal origin and for those of plant origin.

\section{Generic Characteristics of Handheld Devices}

\subsection{Technologies Available in Miniaturised Form}

While several technologies that have been used in the past as bench-top instruments to assess food authenticity are being tested in miniaturised form in prototypes, only some have passed the proof-of-concept stage and are available in handheld and lightweight, portable forms. Promising miniaturised technologies include optical sensors, imaging sensors, nuclear magnetic resonance spectroscopy (NMR), and sensor arrays (Table 1).

Table 1. Technologies for food authentication available in miniaturised form: variants of optical sensors, imaging sensors, sensor arrays, and NMR devices.

\begin{tabular}{|c|c|c|c|c|c|}
\hline Technology & Details & Feature Measured & Availability & $\begin{array}{c}\text { Stage } \\
\text { (Prototype/Commercial) }\end{array}$ & $\begin{array}{l}\text { Literature (Original } \\
\text { Articles and } \\
\text { Reviews) }\end{array}$ \\
\hline \multirow{8}{*}{ Optical sensors } & Reflectance & Colour (CIE lab) & Handheld & C & [17] \\
\hline & $\begin{array}{l}\text { Reflectance, } \\
\text { absorption, } \\
\text { fluorescence }\end{array}$ & VIS spectrum & Handheld & $\mathrm{P} / \mathrm{C}$ & [18] \\
\hline & $\begin{array}{l}\text { Reflectance, } \\
\text { absorption }\end{array}$ & FLUO spectrum & Handheld & $\mathrm{P} / \mathrm{C}$ & {$[18,19]$} \\
\hline & $\begin{array}{l}\text { Reflectance, } \\
\text { absorption }\end{array}$ & NIR/SWIR spectrum & Handheld & $\mathrm{P} / \mathrm{C}$ & {$[12,20]$} \\
\hline & Reflectance & FTIR spectrum & Portable & $\mathrm{P} / \mathrm{C}$ & {$[21,22]$} \\
\hline & Reflectance & MIR spectrum & Portable & $\mathrm{P}$ & {$[21,23]$} \\
\hline & Raman scattering & Scattered light & Portable/handheld & C & {$[13,20,24]$} \\
\hline & LIBS & $\begin{array}{l}\text { Emitting light from } \\
\text { plasma cooling }\end{array}$ & Portable & $\mathrm{P} / \mathrm{C}$ & [25] \\
\hline \multirow{3}{*}{ Imaging } & $\begin{array}{l}\text { Reflectance, } \\
\text { fluorescence }\end{array}$ & VIS spectrum & Portable & $\mathrm{P} / \mathrm{C}$ & {$[18,26,27]$} \\
\hline & Reflectance & SWIR spectrum & Portable & $\mathrm{P} / \mathrm{C}$ & {$[26,27]$} \\
\hline & Scattering & Raman spectrum & Portable & $\mathrm{P}$ & {$[24]$} \\
\hline \multirow{3}{*}{$\begin{array}{c}\text { NMR } \\
\text { Sensor arrays }\end{array}$} & NMR & NMR spectrum & Portable & $\mathrm{P}$ & [28] \\
\hline & Electronic Nose & Volatile compounds & Handheld & $\mathrm{P} / \mathrm{C}$ & {$[10,29-33]$} \\
\hline & Electronic Tongue & Solutes & Portable & $\mathrm{P}$ & {$[30,34-36]$} \\
\hline
\end{tabular}

VIS = visible spectroscopy; FLUO = fluorescence spectroscopy; NIR = near-IR spectroscopy, SWIR = short-wave IR spectroscopy; FT-IR = Fourier-transformed IR; MIR = mid-IR; NMR = nuclear magnetic resonance spectroscopy; LIBS = Laser-induced breakdown spectroscopy; $\mathrm{C}=$ commercial $; \mathrm{P}=$ prototype.

\subsubsection{Optical Sensors}

Miniaturised optical sensors that have been applied may scan from ultraviolet (UV, $200 \mathrm{~nm}$ ) to visible (VIS, $700 \mathrm{~nm}$ ), and infrared (IR, $2400 \mathrm{~nm}$ ) wavelengths. Most devices collect the diffuse reflectance or fluorescence spectra arising from interaction of light with solid, paste-like, and even liquid (food) samples. The latter is then called transflectance 
spectroscopy as the light travels through the liquid sample, reflects at a standardised material, and travels back through the liquid sample to the detector $[17,18,20,37]$. Depending on this sample constitution and the set of wavelengths used, the penetration depth varies [38]. In contrary to the aforementioned spectrometers, Raman devices collect the spectrum of vibrations upon the interaction of a monochromatic laser light with the sample, and laser-induced breakdown spectroscopy (LIBS) detects the light that emits during the cooling process of plasma produced by the absorption of a laser pulse (Table 1).

\subsubsection{Imaging Sensors}

Further devices with miniaturised technologies for food screening carry imaging technologies like cameras. For example, prototypes of cameras were used to successfully discriminate horse meat from beef [39] and to assess fruit quality parameters [40-44], fruit bruising [45], or vigor and vegetative expression of vines [46]. The combination of an imaging tool (camera) with technologies like UV, VIS, near-infrared (NIR) as well as Raman spectroscopy is called spectral imaging (Table 1). Thereby, multiple forms are possible, such as hyperspectral imaging (HSI), linescan imaging, and multispectral imaging. HSI collects a three-dimensional hyperspectral data cube that contains not only spectral data but also spatial data. Several prototypes have been described in literature for food fraud testing, e.g., Raman imaging for milk powder authentication [47] or apple contamination [48], short-wave infrared HSI on nut quality [49], or hyperspectral imaging for contamination detection [50-52]. Steps to valorise smartphone cameras have been reviewed by Rateni et al., 2017 [11], and McGonigle et al., 2018 [53].

\subsubsection{NMR}

NMR has been miniaturised to portable and unilateral NMR devices with an open geometry of the respective magnet. Multiple prototypes have been developed and tested in accordance to their food analysis capabilities, ranging from meat and fish to dairy and fruits [30]. Recently, the analysis of packaged foodstuffs [54] and thick samples was researched $[55,56]$. Nevertheless, commercially available, handheld NMR devices are currently not on the market $[30,57]$, and assessments of food authenticity or food fraud detection in a nontargeted manner are lacking.

\subsubsection{Sensor Arrays (Electronic Nose and Tongue)}

Whereas the previously mentioned sensors are able to measure a fingerprint of the samples, electronic tongue and nose provide, in addition, selective information on the samples' ingredients. Both tools intend to mimic the human gustatory and olfactory receptors. Although multiple sensors are available, only a few have been miniaturised. Specific volatiles may be detected by portable electronic noses commonly using conductometric sensors, piezoelectric sensors, or odour-imaging sensor arrays. In contrast, portable electronic tongues detecting solutes in liquids are usually based on amperometry, voltammetry, potentiometry, impedimetry, conductometry, or on a combination thereof (Table 1). There are only a few devices commercially available that may be applied as electronic nose. Several others were tested at prototype stage to assess the authenticity of products of plant origin [58,59].

In the following sections, only devices are included that are (1) available for purchase and are ready-to-use and (2) have been reported in food authenticity assessments in the scientific literature or are aimed at features that could be used for food authentication.

\subsection{Design and Mode of Operation of Commercially Available Handheld Devices}

Commercially available handheld devices come in various forms and shapes. Whereas devices carrying optical sensors applying reflectance UV-VIS and IR spectroscopy are available in smaller versions, such as the size of a match box, ones applying laser excitation such as Raman spectroscopy and LIBS are heavier and bulkier. Similar to the latter, imaging devices tend to be larger (Figure 1). Sensor arrays may be implemented in both small and 
large devices. Although weight and size depend to some extent on the type of technology, some come in large, heavy versions as well as smaller, lighter varieties of devices. Thereby, the size depends on the technology's parameters used. For example, different IR detectors can run either with or without extra cooling: in small-wavelength ranges, mostly no cooling is required, but additional hardware for cooling is needed when operating at higher wavelengths. Moreover, some instruments are equipped with additional features such as displays or handles, which expand the size and weight of the instruments.

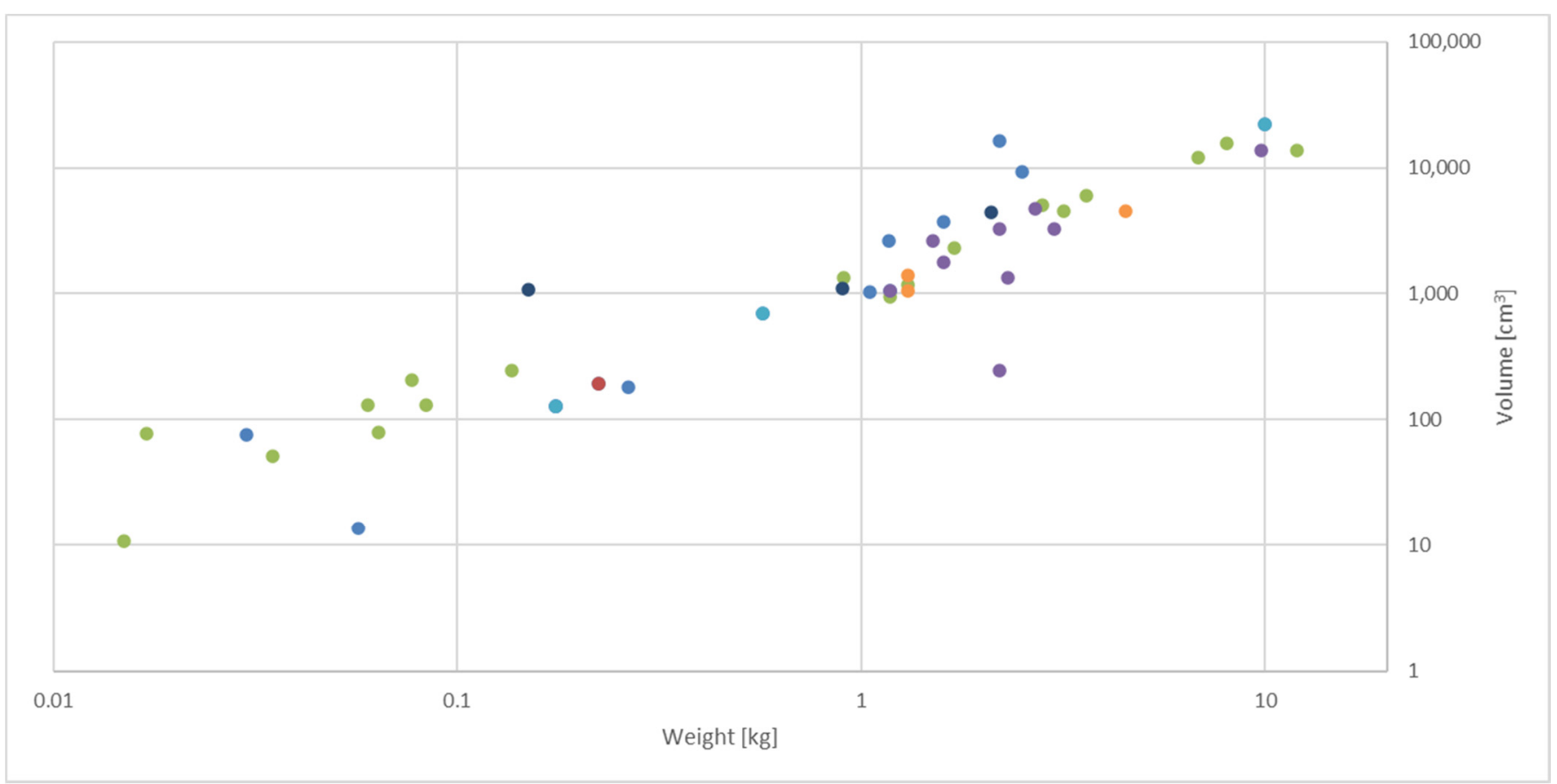

Figure 1. Overview of weight and volume (height $\times$ width $\times$ length) distribution of some selected commercially available devices used for food authentication according to type of technology (only devices where both weight and size/volume are available are included). $=$ ultraviolet-visible spectroscopy $(n=14) ;$ spectroscopy $(n=18) ; \quad=$ Raman spectroscopy $(n=9) ; \quad=$ laser-induced breakdown spectroscopy $(n=3)$; $=$ imaging $(n=3) ; \quad=$ sensor arrays $(n=3)$. Details of all devices are provided in Supplementary Material-Table S1.

For example, within optical NIR sensors, the lightest commercially available NIR device is the Scio (Consumer Physics, Herzliya, Israel), weighing $0.035 \mathrm{~kg}$ and fitting with $6.77 \mathrm{~cm} \times 4.02 \mathrm{~cm} \times 1.88 \mathrm{~cm}$ in a hand palm. It is operated via an application on a mobile phone and scans a range from 740 to $1070 \mathrm{~nm}$. In contrast, the LabSpec (Malvern Panalytica, Almelo, the Netherlands (former ASD)) weighs $12 \mathrm{~kg}$ and is $12.7 \mathrm{~cm} \times 36.8 \mathrm{~cm}$ $\times 29.2 \mathrm{~cm}$ size. The latter NIR device is equipped with a detector for a larger scanning range, $350-2500 \mathrm{~nm}$, and does not need an external operator.

\subsection{Data Handling and Output of the Handheld Devices}

All handheld devices have in common that a database with reference values and/or calibration curves is necessary to ensure the foods' integrity [60]. While a database containing food fingerprints is usually custom-made, e.g., for geographical origin determinations of ham or for the grade of olive oil, some databases contain spectra of common adulterants or contaminants in various concentrations for spectral matching. The databases are tailormade for each device, and only lately approaches and algorithms have been developed to make databases/reference values applicable for multiples devices [7]. Some companies have open-access databases that are populated by users, such as, for example, Scio (Consumer Physics, Herzliya, Israel). Other companies offer the possibility to purchase 
tailormade databases or support creation of one by the applicant, such as all devices of ThermoFisher Scientific (Waltham, MA, USA).

Often pretreatment needs to be applied to spectroscopic data to convert the spectra from reflectance to absorbance values, reduce unwanted light-scattering effects, and to eliminate baseline shifts and background information (noise) in the data. In case of spectral imaging, the 3D data cube needs to be transferred into 2D and the spectral data treated consecutively. Depending on the aim, three different kinds of approaches in modelling may be applied: (1) classifying or discriminating normal from unusual, which is called "broad anomaly testing", (2) classifying or discriminating different (multiple) groups, e.g., species, varieties, and geographical origins, and (3) measuring the degree of adulteration in case there is a limit of adulterant that is still legal. Commonly used chemometrics for the pretreatment of spectroscopic data, the construction of models based on it, and their transfer between instruments and food commodities have been addressed by Capitan-Vallvey and Palma, 2011 [61], Oliveira et al., 2019 [6], and McGrath et al., 2018 [7]. Similar approaches are used in the application of electronic noses and tongues as recently summarized and reported by $[31,33,37]$.

\section{Current Applications of Handheld Devices for Food Authentication}

The current applications in food authentication with commercial, handheld devices target products of animal origin as well as plant origin. In the following sections, applications and their performance indicators (classification rates, accuracy, etc.) are reviewed according to food commodity. For each commodity group, applications are presented in order of applied technologies: VIS, fluorescence spectroscopy, NIR, Fourier-transformed IR (FT-IR), mid-IR (MIR), Raman spectroscopy, LIBS, imaging, and sensor arrays.

\subsection{Food Products of Animal Origin}

\subsubsection{Meat, Meat Products, and Offal}

In the scientific literature on the authentication of meat, meat products, and offal, only one handheld device using solely VIS wavelengths from 400 to $700 \mathrm{~nm}$ was reported. Dian et al., 2008 [62], classified the feeding regime of, respectively, 91\% and 99\% of pasturefed and stall-fed lambs correctly. In spite of the former study, most applications included multiple wavelength ranges or technologies, such as VIS-NIR, NIR, Raman, LIBS, and sensor array technology (Supplementary Material-Table S2).

With VIS-NIR devices, indirect authentication of pig carcasses according to feeding regime has been proven successful. Perez-Marin et al., 2009 [63], predicted fatty acid concentrations in the transverse section of pig carcasses, in particular, linoleic acid $\left(R^{2}\right.$ CAL 0.64$)$, oleic acid $\left(R^{2}\right.$ CAL 0.90$)$, stearic acid $\left(R^{2}\right.$ CAL 0.84$)$, and palmitic acid $\left(R^{2}\right.$ CAL $0.93)$. These fatty acids were subsequently used to assess the feeding regimes. Similarly, Prieto et al., 2018 [64], showed that the ratio between polyunsaturated and saturated fatty acids $\left(R^{2}\right.$ value of 0.93 and Root mean square error of cross-validation (RMSEP) of $0.019 \%)$ and iodine value $\left(R_{P}^{2} 0.94\right.$ and RMSEP $\left.1.03 \%\right)$ could be predicted reasonably well. Prieto et al., 2015 [65], detected the unapproved postmortem moisture enhancement of pork with salt and di-sodiumphosphate solution using a wavelength range of 350 to $2500 \mathrm{~nm}$. Non-moisture-enhanced and moisture-enhanced samples, respectively, were correctly identified after two days of aging with a success rate of $99 \%$ and $94 \%$, respectively. After 14 days of aging, $94 \%$ of the same non-moisture-enhanced samples and $92 \%$ of the moisture-enhanced samples could still be correctly classified. Dixit et al., 2020 [66], evaluated two sensors, a VIS-NIR (350-2500 nm) and a NIR device (900-1700 nm), to determine the age of slaughtered lambs. The authors concluded that both sensors were able to differentiate two age groups, i.e., the early ( 4 months) and late-season (12 months) lambs.

In addition, NIR devices using solely wavelengths above $700 \mathrm{~nm}$ (Supplementary Material-Table S2) showed promising results when applied for the authentication of meat, meat products, and edible offal. To authenticate the correct premium classifications based on feeding regimes of pigs, different NIR devices were tested. Using a wavelength range 
from 900 to $1700 \mathrm{~nm}, 93 \%$ [67] to $99 \%$ [68] of all samples were identified correctly. In contrast, Zamora-Rojas et al., 2012 [69], achieved a correct classification rate of $61-96 \%$ for pork carcasses. Horcada et al., 2020 [70], reported a 76\% correct classification rate when distinguishing free-range pork carcasses, carcasses from animals fed on acorns and grass with supplements, and ones from animals fed on compound feeds with the same instrument. Moreover, a high correct classification rate was determined for chicken meat quality classifications based on feeding regime. Over $95 \%$ were correctly identified according to standard feeding, free-range, or corn-fed feeding as well as the feeding regimes according to the Dutch animal welfare classification system ranging from conventional to organic [71]. Great classification predictions were reported when discriminating chicken parts $(99 \%$ correct) when using a wavelength range of 900-1700 $\mathrm{nm}$ [72] or when discriminating different species. Dumalisile et al., 2020 [73], applied a range between 908 and $1700 \mathrm{~nm}$ to classify different game species and achieved $81 \%, 92 \%$, and $97 \%$ correct classification for impala, ostrich, and eland muscles, respectively. When mixing veal sausages with pork or pork fat, a 100\% correct discrimination rate above a 10\% $(w / w)$ adulteration level was established by Schmutzler et al., 2015 [74]. Similar discrimination results were obtained in ground meat blends, e.g., in binary blends of chicken/beef $\left(\mathrm{R}^{2} \mathrm{p}\right.$ 0.99, RMSEP $\left.3.5 \%(w / w)\right)$ and ternary blends of beef/chicken/pork $\left(\mathrm{R}^{2} \mathrm{p}\right.$ 0.93, RMSEP $\left.4.7 \%(w / w)\right)$ by Silva et al., 2020 [75].

To identify substitution of meat products with meat from other species or offal, portable LIBS sensors have been evaluated as well. Bilge et al., 2016 [76], evaluated minced beef blended with pork or chicken in a ratio of $10-50 \%(w / w)$. Using the fivechannel Aurora LIBS spectrometer, determination coefficients $\left(\mathrm{R}^{2}\right)$ and limits of detection (LOD) of 0.994 and $4.4 \%$ for pork adulteration and 0.999 and $2.0 \%$ for chicken adulteration, respectively, were reported. Less successful but still worth mentioning was the detection of minced beef substituted with offal (liver) indirectly via copper concentrations with a $R^{2} p$ of 0.85 and an RMSEP of 37 ppm by Casado-Gavalda et al., 2017 [77].

In brief, the macro composition of meat products may be detected sufficiently using NIR technology, which allows the detection of fraudulently added moisture to meat products. By adding the VIS wavelength results, greater precise is achieved and maybe also detailing of minor components, such as fatty acid concentrations, allowing further details of authenticity traits such as species detection or production system. Hence, classifications on organic or nonorganic, feeding style, as well as breed might be conducted successfully using NIR devices or VIS-NIR devices. The detection of meat substitution by meat from other species or offal may be detected using both NIR and LIBS devices. Despite the above, there is still limited information about the abilities of VIS, LIBS, Raman spectroscopy, and fluorescence spectroscopy, as well as spectral imaging and sensor array applications for meat authentication.

\subsubsection{Milk and Milk Products}

Applications for the authentication of milk and milk products are listed in Supplementary Material-Table S3. The application of VIS devices and ones applying fluorescence spectroscopy for the authentication of milk and milk products is limited. One device was applied to assess the feeding regime of cows in cheeses derived from the cows' milks using a wavelength range between 400 and $700 \mathrm{~nm}$. In this case, $79 \%$ to $91 \%$ of the cheeses were classified correctly, which is considerably lower than the $96 \%$ correct classification achieved using a benchtop NIR device in the same study [78].

Several scientific reports evaluated the ability to assess authenticity according to fat, protein, and carbohydrate content (especially lactose) of milk and milk products with NIR. Uusitalo et al., 2019 [79], compared three portable NIR sensors, covering wavelength ranges of $1100-1400 \mathrm{~nm}, 1700-2000 \mathrm{~nm}$, and $2200-2500 \mathrm{~nm}$ in regard to their ability to assess fat, protein, and lactose contents of raw milk, drawing subsequent conclusions on the feeding regime of the cows. The authors concluded that the prediction was successful, however not sufficient for the application by legal entities. Using the VIS wavelength range and parts of the shortwave NIR range (400-995 nm), Bogomolov et al., 2017 [80], were 
able to sufficiently predict fat content $\left(\mathrm{R}^{2} \mathrm{CV} 0.975 \mathrm{RMSECV} 0.090 \%\right)$ and protein content $\left(\mathrm{R}^{2} \mathrm{CV} 0.84 \mathrm{RMSECV} 0.079 \%\right)$ in retail milk, which was used to authenticate genuine milk. Despite the low success rates for quantification of the carbohydrate content in previous studies, de Lima et al., 2018 [81], reported that application of a wavelength range from 908 to $1676 \mathrm{~nm}$ was sufficient to conduct a $100 \%$ successful two-group classification, i.e., between lactose-free milks and regular milks.

In cheeses, the prediction of macro-component concentrations was similar to those in milk, with the fat and moisture contents being sufficiently predicted but the protein content remaining challenging. For instance, Ma et al., 2019 [82], applied a wavelength range of 740 to $1070 \mathrm{~nm}$ for cheese protein assessments, but intact casein $\left(\mathrm{R}^{2}{ }_{\mathrm{P}} 0.61-0.70\right.$, RMSEP $0.91-1.58 \mathrm{~g} / 100 \mathrm{~g})$ and total protein content $\left(\mathrm{R}_{\mathrm{P}}^{2} 0.54-0.62\right.$, RMSEP $\left.0.62-0.88 \mathrm{~g} / 100 \mathrm{~g}\right)$ were only approximately predicted.

The discrimination of farming regimes, particularly dairy products from organic and nonorganic production systems, was reported to be classified correctly with a 73-89\% accuracy in retail milk samples [83]. Furthermore, Behkami et al., 2019 [84], reported a $100 \%$ correct classification rate in regard to the geographical origin of freeze-dried milk applying a range from $200-2600 \mathrm{~nm}$.

Substitution of milk products to boost the protein content measured by wet-chemical methods or the addition of cheap ingredients to increase volume and weight has occurred mainly in milk powders and infant foods in the past. Milk powder substituted with melamine, dicyandiamide, aminotriazole, biuret, cyanuric acid as low-molecularweight, nitrogen-rich compounds, inorganic salts (ammonium sulfate and calcium carbonate), soy protein isolate, pea protein isolate, maltodextrin, and sucrose was analysed by Karunathilaka et al., 2018 [85]. In line with the low prediction rates of protein contents in the aforementioned studies, specificity was low, and only biuret-spiked samples were sufficiently identified above $0.4 \%(w / w)$ biuret in blends. Another unapproved enhancement of milk powders is reported to be the treatment with gamma-irradiation to improve the microbial quality illicitly. Kong et al., 2013 [86], studied milk powder samples with doses of $0,1.5,3.0,4.5$, and $6.0 \mathrm{kGy}$ irradiated with $60 \mathrm{Co} \gamma$-rays using a dose rate of $2 \mathrm{kGy} / \mathrm{h}$ that were subjected to NIR measurements in the range of $325-1075 \mathrm{~nm}$. Best prediction results were achieved by application of selecting an effective wavelength and extreme learning machine models $\left(R_{P}^{2} 0.97\right.$ and RMSEP of 0.844$)$.

Overcoming the limitations of NIR devices on compositional prediction of dairy products, a portable device that scans the MIR region between 4000 and $650 \mathrm{~cm}^{-1}$ was successfully applied to predict protein, fat, and carbohydrate contents with values for $R^{2} \mathrm{P}$ of $0.96,0.69$, and 0.92 , respectively, and for RMSECV of $0.22,0.63$, and $0.40 \mathrm{~g}$ macronutrients $/ 100 \mathrm{~mL}$, respectively [25]. In the same range, Limm et al., 2018 [23], reported a successful classification of melamine-adulterated milk powders with a $100 \%$ correct classification rate for wet-blended and dry-blended mixtures above $0.3 \%(w / w)$ and $1.0 \%$ $(w / w)$, respectively. Milk powders were spiked with melamine from $3 \%$ to $10 \%(w / w)$ and analysed with Raman technology recording 200 to $2000 \mathrm{~cm}^{-1}$. Results showed a good prediction with an $R^{2}$ of 0.995 and an RMSECV of 33.60 [87].

One disadvantage of LIBS is the challenging measurement of liquid samples. According to Sezer et al., 2018 [88], the interaction of the laser beam and the liquids leads to splashing on the detector node as well as aerosol and ripple formation of the sample. Overcoming these issues, Moncayo et al., 2017 [89], used freeze-dried and pelleted milk. With LIBS technology, different origins of milk, i.e., cow, goat, and sheep as well as mixtures thereof, were classified $100 \%$ correctly. Furthermore, the addition of melamine to milk was quantified at a high accuracy $\left(R^{2} 0.999\right)$. Another option for preprocessing was reported by Sezer et al., 2018 [88], using the Applied Spectra five-channel Aurora LIBS spectrometer. The authors prepared gel samples using gelatin and successfully identified adulterations of caprine and ovine milk blended in bovine milk (caprine $R^{2}{ }_{v} 0.993$, RMSEP 3.56; ovine $\mathrm{R}^{2}{ }_{\mathrm{v}} 0.995$, RMSEP 4.53). The same device was also used to detect butter adulterated with margarine from $5 \%$ to $50 \%(w / w)$, leading to $R^{2}{ }_{v}$ of 0.984 and RMSEP of 3.37. Bilge et al., 
2016 [90], analysed whey adulteration of milk powder from $1 \%$ to $40 \%(w / w)$ by LIBS. The authors reported high $\mathrm{R}^{2}$ v values of 0.981 for sweet whey and 0.985 for acid whey, indicating a successful detection of whey adulteration in milk powder.

In brief, the prediction of milk and milk products' components as well as the substitution or dilution with fraudulent substances is challenging for VIS and NIR devices. In contrast, devices applying MIR, Raman spectroscopy, or LIBS technology are more competent to predict the macro composition and classify correctly. The latter, however, needs for liquid dairy samples an additional pretreatment because liquids are not suitable for this type of measurement.

\subsubsection{Fish and Seafood}

Two different NIR devices have been used for the authentication of fish (Supplementary Material-Table S4). Grassi et al., 2018 [91], found a 100\% correct classification rate for both fillets and patties using a handheld NIR (950-1650 nm) to discriminate Atlantic cod and haddock. Accordingly, O'Brien et al., 2013 [92], reported a successful classification of fish species (cod/winter cod, mullet/red mullet, and samlet/salmon trout) on whole fish and fillets using a similar instrument. Imaging was used to evaluate fish authenticity via the key factor moisture content. He et al., 2013 [93], reported a successful determination of the moisture content of salmon using two HSI systems with spectral ranges of 400-1000 nm and 897 to $1753 \mathrm{~nm}$, respectively. Both devices delivered information that was valuable for the classification, resulting in $R^{2}{ }_{P} 0.893$, RMSEP $1.513 \%$ for the $400-1000 \mathrm{~nm}$ range and $\mathrm{R}^{2} \mathrm{P}$ 0.902, RMSEP $1.450 \%$ for the $897-1753$ range.

Concerning fish and seafood authenticity assessments, wavelength ranges in the NIR range have been mostly applied, both for single point measurements and for imaging. In addition, sensor arrays, such as electronic noses, might be useful to detect authenticity traits, particularly those related to freshness, in samples that are thick or covered with skin.

\subsubsection{Other Food Products of Animal Origin}

Other food products of animal origin received little attention (Supplementary MaterialTable S5). One study on the freshness of eggs (storage time) was reported using NIR [94]. Honey is the other product of animal origin that received some attention. Using a range between 950 and $1630 \mathrm{~nm}$, Kaszab et al., 2017 [95], were able to predict 100\% of the floral origin of honeys, i.e., linden, acacia, polyfloral, and chestnut honey. Similarly, the geographical origin could be predicted with a success rate of 96\%. Moreover, Lastra-Mejías et al., 2020 [96], and Stefas et al., 2020 [97], discriminated the nectar and geographical origin of honey. The authors reported accuracies between $96 \%$ and 100\% using LIBS technology. In addition, Lastra-Mejías et al., 2020 [96], were able to correctly detect adulteration of honey with rice syrup with a success rate of up to $96 \%$.

\subsection{Food Products of Plant Origin}

\subsubsection{Fresh and Dried Food Products of Plant Origin}

Depending on the fresh fruit appearance, i.e., peel thickness, transparency of the edible parts, and fruit volume, or the homogeneity of the plant-based product, the abilities of portable devices to assess their authenticity (listed in Supplementary Material-Table S6) were more or less successful. Whereas VIS and fluorescence technology devices are known to not penetrate the skin of fruits, NIR wavelength ranges allow measurements of parts of the tissue below the fruit or vegetable skin. Hence, only limited reports on the application of a handheld device in the VIS range (380-700 nm) and fluorescence were found. Vincent et al., 2018 [98], reported a 93\% accuracy in discriminating different varieties of apples. Despite this successful application, the follow-up approach with the same samples and device differentiating organic and nonorganic apples was not successful. Recording a similar wavelength range but with monochromatic light inducing fluorescence, Dong et al., 2014 [99], were able to classify teas according to the type of cultivar and type of processing (green or black tea). 
Applications of VIS-NIR and NIR devices have been more frequently used for authenticity assessments than has only VIS based technology since they are able to determine the macro composition, i.e., water, protein, and fat contents, in addition to secondary metabolites. In the wavelength range 450-1000 nm, You et al., 2017 [100], were able to discriminate $100 \%$ of powders from various plant sources with differing macro composition, such as wheat, bean, corn, rice, and potato in addition to salt and sugar. Similarly, Toivonen et al., 2017 [101], authenticated cherry breeds with differing dry matter content with a device using 285 to $1200 \mathrm{~nm}\left(\mathrm{R}_{\mathrm{P}}^{2}>0.9\right.$, RMSEP $\left.<0.74 \%\right)$. Fruits with a similar macro composition but with differing secondary metabolite composition, such as bananas, were also authenticated using a VIS-NIR device in the 367-2388 nm range (carotenoid concentration in pulp: $\mathrm{R}_{\mathrm{P}}^{2} 0.96$; RMSEP $28.70 \mathrm{nmol} / \mathrm{g}$ dry weight). Thereby, $\beta$-carotene content was best predicted and-in descending order of accuracy-also $\alpha$-carotene, c-carotene, and lutein contents [102]. Moreover, with VIS-NIR devices, Ikeogu et al., 2017 [103], successfully authenticated cassava roots according to their total carotenoids $\left(\mathrm{R}_{\mathrm{P}} \mathrm{0.88}\right)$ and dry matter $\left(R_{P}^{2} 0.80\right)$ content, and Szuvandzsiev et al., 2014 [104], discriminated tomato breeds with differing lycopene contents $\left(R^{2} \mathrm{CV}\right.$ 0.75, RMSECV $\left.7.63 \mathrm{mg} / 100 \mathrm{~g}\right)$, soluble solids content $\left(\mathrm{R}^{2} \mathrm{CV}\right.$ 0.77, RMSECV $0.51^{\circ}$ Brix), and polyphenol contents $\left(\mathrm{R}^{2} \mathrm{CV} 0.72\right.$, RMSECV $1.99 \mathrm{mg} / 100 \mathrm{~g}$ ). Further applications of VIS-NIR devices in the authenticity assessment of fresh and dried plant-based products include the detection of wheat flour added to unripe banana flour (0-800 $\left.\mathrm{g} \mathrm{kg}^{-1}\right)$. For instance, Ndlovu et al., 2019 [105], detected this type of adulteration in high precision $\left(R_{\mathrm{P}}^{2} 0.99\right.$, RMSEP $\left.1.99 \mathrm{~g} \mathrm{~kg}^{-1}\right)$ with a VIS-NIR device measuring from 447 to $1005 \mathrm{~nm}$. Similarly, Rukundo and Danao, 2020 [106], used a handheld VIS-NIR device (780-2500 $\mathrm{nm}$ ) to successfully detect turmeric powder adulterated with the same product from 0 to $30 \%$. Sugarcane was analysed in the range between 300 and $1100 \mathrm{~nm}$ to distinguish grades [107]. The authors reported an $83 \%$ correct classification rate of premium grades (Brix-oriented). A good correlation with the mineral content $\left(\mathrm{R}^{2} \mathrm{P}\right.$ 0.78-0.93, RMSEP $0.57-27.30 \mathrm{mg} 100 \mathrm{~mL}^{-1}$ ) was also reported by [108]. This content was used to identify growing regimes. Similarly, Jamshidi et al., 2016 [109], classified fresh products according to their farming regime. In a range between 450 and $1000 \mathrm{~nm}$, the authors reported a $92 \%$ correct prediction rate of all samples, while $100 \%$ of the unsafe samples were correctly identified. Guidetti et al., 2010 [110], determined differences in the VIS-NIR spectra of grapes from different origin.

Food authentication applications have also been described for NIR devices applying wavelength ranges above $700 \mathrm{~nm}$. Tea varieties were successfully discriminated according to their catechin and caffeine content $\left(R^{2}{ }_{\mathrm{P}}>0.91\right.$, RMSEP $<10.64 \mathrm{mg} / \mathrm{g}$, [111]), bean breeds according to their protein, starch, and amylose content $\left(R^{2} \mathrm{CV}>0.91\right.$, [112]), plum varieties in relation to soluble solids content $\left(R^{2} \mathrm{CV} 0.57,[113]\right)$, and sugar beets in regard to their sucrose contents $\left(R^{2} P>0.75\right.$, [114]). Furthermore, peanuts were discriminated in valuable high-oleic-acid peanuts and regular peanuts with an up to $100 \%$ correct classification rate using a portable NIR [115]. When discriminating different varieties, $84 \%$ of fengdou from Dendrobium officinale Kimura et Migo (DOK) was correctly predicted in comparison to fengdou from another variety by applying a wavelength range from 908 to $1676 \mathrm{~nm}$ [116]. Assessing the feasibility of adulteration detection with handheld NIRs, blended Arabica coffee with peels/sticks or corn, in the concentration range from 1 to $100 \%(w / w)$, was analysed by Correia et al., 2018 [117], using a microNIR device in the wavelength range 908-1676 nm. While a good prediction was registered for the detection of corn adulteration $\left(R^{2}{ }_{P} 0.98\right.$, RMSEP $\left.4.0 \%\right)$, the detection of peels / sticks was less successful $\left(R_{P}^{2} 0.86\right.$, RMSEP $11.4 \%$ ), possibly due to the greater similarity of the adulterant and the authentic sample. The authors further studied the detection of roasting levels in mixtures of Arabica and Robusta coffee, and found good prediction results $\left(\mathrm{R}^{2} \mathrm{P}>0.96\right.$, RMSEP $<6.6 \%$, [117]). Oliveira et al., 2020 [118], mixed three types of paprika powder with potato starch and acacia gum to boost volume and annatto to intensify the colour. Using a DLPR NIRscanTM Nano device (wavelength range $900-1700 \mathrm{~nm}$ ), they were able to classify over $90 \%$ of the samples correctly $\left(\mathrm{R}_{\mathrm{P}}^{2} 0.87-0.97\right.$, RMSEP $\left.1.68-2.12 \%\right)$. In the same wavelength range but 
with another NIR device, turmeric adulteration with metanil yellow (1-25\%) $(w / w)$ was detected with high accuracy $\left(\mathrm{R}_{\mathrm{P}}^{2}>0.96\right.$, RMSEP $<0.89 \%$, [119]). Adulterated oregano with cistus, myrtle, olive leaf, and sumac was correctly classified by up to $98 \%$, in addition to $93 \%$ of the authentic oregano classifications, using a miniaturised NIR device [120]. In the wavelength range from 1600 to $2400 \mathrm{~nm}$, spiked soy bean samples with melamine $(0.25-2 \%$ $(w / w))$ could be predicted in a high precision with $\mathrm{R}^{2}$ values from 0.94 to 0.99 and RMSEP values around $0.08-0.22 \%$ [121]. Of bell pepper samples from different growing regimes, such as those grown outdoors or in greenhouses, $88-91 \%$ were correctly classified using another NIR device (1600-2400 nm, [122]). For detecting organic and nonorganic growing regimes, NIR devices were applied successfully on tomatoes [123] and apples (accuracy $96-98 \%$, [124]). To identify growing regimes with fraudulent fertilizer use, the nitrogen content in olive leaves (accuracy 83\%, [125]) and spinach leaves (correct classification rate 75-80\%), [126] NIR devices were successfully applied. Some fresh and dried plant-based products were also classified according to their geographical origin using NIR devices. Teye et al., 2019 [127], reported an over 90\% correct classification rate of rice of different quality grades, countries of origin, and imported versus local production by applying a portable device in the wavelength range of 740-950 nm. Similarly, Zhu and Tian, 2018 [128], identified the geographical origin of apples with an NIR device (900-1700 nm).

By applying MIR wavelength ranges, Manfredi et al., 2018 [129], reported an accuracy of $98 \%$ in the classification of different hazelnut cultivars.

Using a handheld Raman device, Guzman et al., 2012 [130], correctly classified 97$100 \%$ of olive fruits by their harvesting manner, e.g., picked from trees and collected from the ground. Krimmer et al., 2019 [131], showed that a handheld Raman device could be used to correctly classify $89-98 \%$ of maize kernel according to variety and estimation of nutrient content, i.e., carbohydrates, carotenoids, fibres (lignin), and protein. In a study with limited samples, Vargas Jentzsch et al., 2016 [132], showed that Raman devices may be used to detect counterfeit stevia products.

Perez-Rodriguez et al., 2019 [133], and Yang et al., 2018 [134], used portable LIBS devices to classify rice according to its geographical origin with a $84 \%$ and $99 \%$ accuracy, respectively, for the two instruments. Moreover, coffee adulterated with wheat, corn, and chickpeas was successfully discriminated from authentic coffee using LIBS technology $\left(\mathrm{R}^{2} \mathrm{P}\right.$ 0.99, RMSEP 6.68-7.85\%, [135])

Nutmeg adulterated with 5-60\% low-quality plant parts was subjected to HSI, and adulteration was predicted with high accuracy $\left(R^{2} P>0.91\right)$. Similarly, Su and Sun, 2017 [136], classified adulterated organic wheat flour with nonorganic ones as well as adulteration with flours from other plants fairly correctly $\left(R_{P}^{2}\right.$ value $>0.97$, RMSEP $\left.<0.038\right)$ using HSI in a higher wavelength range.

In brief, the application of optical handheld devices is highly dependent on the plant products' physical appearance. While dried and ground products may be assessed by multiple devices, fresh products are challenging. A thick skin, e.g., as occurring with avocados or oranges, as well as inhomogeneities in the products' themselves hinder successful authentication. However, these inhomogeneities enable the discrimination of parts of plant-based products, as shown for sugar cane. To overcome homogeneity issues, a wider range has to be tested, either combining multiple single spot measurements or using HSI. Use of LIBS technology is limited since it can only be applied to dried products.

\subsubsection{Processed Food Products of Plant Origin}

Various applications aiming at processed foods are listed in Supplementary MaterialTable S7. Determination of the constitution of syrups and juices is important to the juice industry to avoid food fraud. Henn et al., 2016 [137], showed that a handheld NIR was able to sufficiently quantitate glucose, fructose, and sucrose in syrups $\left(R^{2}>0.96\right.$, RMSECV $<1.84 \mathrm{~g} / 100 \mathrm{~g})$. Adulteration of lime juice leading to unbalanced citric acid-toiso-citric acid ratios could be detected with 100\% accuracy using a portable NIR device [138]. Moreover, adulterations of tabletop sweeteners (saccharin and cyclamate) with sodium 
saccharin, dextrose, cream of tartar, and calcium silicate $\left(R^{2} \mathrm{P} 0.97\right.$, RMSEP $\left.0.51 \%\right)$, and with sodium cyclamate, dextrose and silicon dioxide $\left(R^{2}{ }_{P} 0.96\right.$, RMSEP $\left.2.8 \%\right)$, respectively, were sufficiently detected using a NIR device [139].

The adulteration of edible oils is a common food fraud issue too, which may be tackled with portable devices. For example, palm oil adulterated with lard from $0.5 \%$ to $50 \%(w / w)$ was detected with an accuracy in the range of $0.93 \%$ to $0.95 \%$ [140] and the adulteration with Sudan dyes (0.5-0.0009\%) with a 91\% to 95\% correct identification rate [141] using a wavelength range from 900 to $1700 \mathrm{~nm}$. Applying the same wavelength range, Yan et al., 2019 [142], were able to successfully discriminate extra virgin olive oil from olive oils of lower quality (94-100\% accuracy) and align most components with respective spectral bands. Moreover, the classification in quality grades according to acid value was successful for peanut oil $\left(R^{2}{ }_{P} 0.94\right.$, RMSEP 0.30, [143]), and palm oil $\left(R^{2}{ }_{P} 0.97\right.$, RMSEP 4.6, [144]). In addition, the dilution with lower-quality oils and the dilution with toxic, nonedible mineral oils in concentration ranges of $0.5-10 \%$ were sufficiently determined $\left(R^{2} \mathrm{CV} 0.99\right.$, RMSEP 0.23-0.32\%) according to the studies of Picouet et al., 2018 [145]. Giovenzana et al., 2014 [146], showed that portable NIR devices were able to evaluate beer quality (soluble solid content and acidity) and also allowed discrimination between filtered and unfiltered beer types.

Using portable MIR technology, 100\% of edible oils from various sources were discriminated from each other $[24,147,148]$. In addition, the detection of adulteration above $10 \%$ edible oil in olive oil $(w / w)$ [24] and the evaluation of oil according to its oxidative status and fatty acid composition were successful $\left(R^{2} v>0.96,[147,148]\right)$.

Bellou et al., 2020 [149], evaluated portable LIBS device settings according to their possibilities to discriminate olive oil from different origins and adulterated samples. Thereby, the classification of olive oil being sprayed delivered a 100\% correct classification rate, whereas laminar flow and free surface configurations provided less accurate results. To avoid splattering using LIBS, Moncayo et al., 2016 [150], prepared gel samples from wines and Tian et al., 2017 [151], dried wine drops before classifying up to $100 \%$ of the samples according to their geographical origins correctly.

Vargas Jentzsch and Ciobotă, 2014 [152], used a handheld Raman device to discriminate up to $100 \%$ of samples correctly according to their variety. Using another Raman handheld device, Zou et al., 2009 [153], reported a distinguishing ability between pure and adulterated olive oils samples above $5 \%(v / v)$.

\section{Handheld Applications: Type of Commodity versus Technology}

Various technologies have been implemented in very small and handy devices that are attractive to users. The applied type of technology and wavelength range vary across applications. An overview of the number of handheld applications according to type of technology and food commodity reviewed in this paper is provided in Table 2.

More applications focus on products of plant origin (92 out of 150) than on products of animal origin (58 out of 150). This is somewhat surprising considering that when food fraud databases are examined, animal products show higher incidence rates than plant-based products do. Furthermore, animal-based product supply chains are in general considerably more vulnerable to fraud than their plant-based counterparts are [154] and would, therefore, require more mitigation measures. Over three quarters of the applications for products of plant origin focus on fresh/dried products. Even those aiming at "processed products" consider relatively simple processed foods, such as juices and oils. Although the number of applications has grown in the past years, it is often already quite complex to authenticate a single component product (e.g., ground beef or a fish fillet) or a food product after limited processing (e.g., a vegetable oil). Even with laboratory-based technology, authentication of composite and/or highly processed food products is still in its infancy. Among the products of animal origin, meat (products) received most attention, followed by milk and milk products. The technology of choice for handheld applications marginally 
differs across product groups. NIR devices appear the most popular technology across the board.

Table 2. Number of studies on handheld applications for food authentication from Supplementary Material-Tables S2-S7 categorised by food product and technology group.

\begin{tabular}{|c|c|c|c|c|c|c|c|}
\hline \multirow[t]{2}{*}{ Technology } & \multicolumn{4}{|c|}{ Products of Animal Origin } & \multicolumn{2}{|c|}{ Products of Plant Origin } & \multirow[t]{2}{*}{ Total } \\
\hline & $\begin{array}{c}\text { Meat, Meat } \\
\text { Products, } \\
\text { and Offal }\end{array}$ & $\begin{array}{l}\text { Milk and } \\
\text { Milk } \\
\text { Products }\end{array}$ & $\begin{array}{l}\text { Fish and } \\
\text { Seafood }\end{array}$ & Others & Fresh/Dried & Processed & \\
\hline VIS & 2 & 1 & - & - & 2 & - & 5 \\
\hline FLUO & 1 & 1 & - & - & 2 & - & 4 \\
\hline VIS-NIR & 4 & 2 & - & - & 17 & - & 23 \\
\hline NIR & 17 & 8 & 3 & 2 & 40 & 10 & 80 \\
\hline MIR & - & 2 & - & - & 1 & 3 & 6 \\
\hline Raman & 1 & 1 & - & - & 4 & 2 & 8 \\
\hline LIBS & 2 & 4 & - & 2 & 3 & 3 & 14 \\
\hline Imaging & 1 & - & 3 & - & 4 & - & 8 \\
\hline Sensor array & - & - & 1 & - & 1 & - & 2 \\
\hline Total-1 & 28 & 19 & 7 & 4 & 74 & 18 & \\
\hline Total-2 & \multicolumn{2}{|c|}{58} & & & \multicolumn{2}{|c|}{92} & 150 \\
\hline
\end{tabular}

VIS = visible spectroscopy; FLUO = fluorescence spectroscopy; NIR = near-IR spectroscopy, MIR = mid-IR (MIR), Raman = Raman spectroscopy; LIBS = laser-induced breakdown spectroscopy.

Most applications used NIR (80 out of 150), followed by VIS-NIR (23 out of 150) and LIBS (14 out of 150). For the other types of technology, such as fluorescence spectroscopy, MIR, Raman spectroscopy, LIBS, imaging, and sensory arrays, a few applications (2-8) have been reported. Spectra generated by the technologies are in some cases indirectly used for authentication purposes. In this approach, spectral data are calibrated against reference methods in order to estimate concentrations of specific compounds or the extent of other types of features (e.g., colour). The compounds/features' numbers are subsequently used for authentication purposes. This approach mimics the procedures for, e.g., protein content measurements using NIR bench top devices, which is very commonly used across the globe. Spectra are also frequently used for fingerprint methods. In this mode, the spectra are directly used to set spectral specifications for product groups, allowing them to be distinguished using multivariate statistics. NIR applications use both types of approaches. The VIS wavelength range is in most cases not useful on its own to authenticate foods. However, the inclusion of the VIS range in addition to a wide NIR (and/or MIR) wavelength range often increases performance. That is one of the reasons why VIS-NIR applications are also relatively popular. In the VIS-NIR applications group, we also find the two types of approaches mentioned above. The benefit of reflectance spectroscopy is its noninvasive nature, and devices are relatively light and compact. Good performance, if products differ clearly in composition, in combination with the practical handling and reasonable costs, has resulted in a large share in the portable authentication applications. However, sometimes a greater depth of excitation wavelength or penetration through package material or thick peels is necessary. For this kind of application, Raman instruments as well as LIBS are favoured. However, the downside of these technologies is that they are found in more bulky and heavier variants than the ones based on reflectance spectroscopy, and liquids are challenging. Another technology that is not used frequently at the moment is fluorescence spectroscopy. This is because of its limited application: only when fluorescent compounds are at stake, e.g., chlorophyll or coumarin, the technology is useful. Similarly, sensor arrays can be useful, but only for unpacked foods that release volatiles or are soluble. This limits broader use of this kind of technology. Imaging and spatially resolved spectroscopy has 
seen also only a few handheld applications so far, but would be in particular useful for authentication issues that can be picked up through inhomogeneity. This may be the case with small-particle-sized products, such as ground spices or other powdered products, which may be extended with other powdered materials.

\section{Outlook}

\subsection{Issues Inhibiting Progress}

As outlined in detail in Sections 3 and 4, there is no single universally applicable technology to assess food authenticity for every food commodity. Adding up to this problem is that for each product and handheld device, a separate (spectral) database needs to be established, making broad implementation of handhelds challenging and potentially expensive. Furthermore, general performance criteria for fingerprint methods are not readily available, they are still under development and discussed in various standardisation groups. Even after the development of a single handheld method for a single product following a defined set of performance criteria, challenges remain for the widespread implementation of the method. The main reason for this is that the handheld methods described in this work rely on predefined databases populated with data from authentic samples. The specific sensor type, brand, or principle and its machine learning statistical procedure to relate unknown sample data to the reference database are not flexible and often not transferrable to other devices or slightly different products.

The rigidity of the specific handheld type, the spectral reference database, and its machine learning protocol is especially applicable to vibrational spectroscopy handhelds or imaging sensors, spanning the wavelength range from VIS to NIR (400-2500 nm). These handhelds deliver spectra with a relatively low information load, compared to their more technically advanced spectroscopy counterparts, MIR, FTIR, and Raman spectroscopy. This means that spectral databases are not directly transferrable to other VIS-NIR hardware types. Specifications in regard to direct comparison of spectra recorded by different devices are lacking as well as for the demonstration of statistical equivalence of the spectra. Consequently, large resources are required for building and maintaining spectral databases. Unlike direct methods, such as mass spectrometry, for every single product and sensor application, this exercise needs to be repeated.

\subsection{Potential Solutions}

An important potential mitigation measure to the above- mentioned issue is innovative data solutions, which could use spectral data published in open-access databases and use data acquired by different types of vibrational spectroscopic devices. Large volumes of spectral data in regard to food authentication have been generated and could be made available and re-used. Such data would need to be available according to the FAIR principle: Findable, Accessible, Interoperable, and Re-usable. Furthermore, the availability of sensor data resulting from measurements on certified (authentic) materials can facilitate the training and validation of handheld methods according to set performance criteria. To enlarge the impact of the available FAIR data, new data solutions are being developed and tested for adequate calibration transfer of this data, next to the currently established procedures. So-called "federated" learning procedures such as dynamic feature selection are being developed to handle the intrinsic heterogeneity of the (authentic) food materials and machine errors presented in the FAIR-data-containing learning networks. Furthermore, the application and development of deep learning tools will facilitate calibration transfer between spectral sensors with a larger difference in hardware configuration, as an elaborate perspective showed by Müller-Maatsch et al., 2021 [60].

Another part of the solution may be the development of more "universal" devices, i.e., the hyphenation or fusion of several spectral technologies into a single device. Hence, the whole spectral region of interest is recorded at once, preferably including imaging and other orthogonal detection techniques. One example that has been recently reported is the hyphenation of fluorescence, VIS, NIR, and imaging technology into a single sensor for 
food authentication. While the NIR sensor provided most of the relevant information to authenticate milk powders [155], the fluorescence sensor was most important in olive oil authentication [156].

An additional trend is to expand the number of spectral sensor operators to cope with the complexity of the food authenticity problem. Implementation of sensing solutions in entire chains is therefore to be expected from farm-to-fork, dealing with several intermediate products and sensor operators. The information gathered from the spectral data can be added to other types of information from the chain, such as mass balance data, and used for assurance of the integrity throughout the chain as well as for detection of anomalies. The information may also be used for decision support systems, allowing actors to put mitigation measures efficiently and effectively in place. In the end, the collated and analysed (spectral) data and outcomes will lead to increased transparency of food supply chain networks.

Supplementary Materials: The following are available online at https:/ /www.mdpi.com/article/10 $.3390 /$ foods10122901/s1, Table S1: Overview of commercially available, portable devices that may be applied for food authentication, their weights and volumes as presented in Figure 1. Table S2: Applications of commercially available devices that may be applied for authentication of meat, meat products, and offal, Table S3: Applications of commercially available devices that may be applied for authentication of milk and milk products, Table S4: Applications of commercially available devices that may be applied for authentication of fish and seafood, Table S5: Applications of commercially available devices that may be applied for authentication of products of animal origin other than those presented in Tables S2-S4, Table S6: Applications of commercially available devices that may be applied for authentication of fresh and dried food products of plant origin, Table S7: Applications of commercially available devices that may be applied for authentication of processed food products of plant origin. References [157-205] are cited in the supplementary materials.

Author Contributions: Conceptualization, J.M.-M. and S.M.v.R.; data curation, J.M.-M. and S.M.v.R.; writing—original draft preparation, J.M.-M.; writing—review and editing, S.M.v.R. All authors have read and agreed to the published version of the manuscript.

Funding: This literature review was funded through the Dutch Statutory Task Programme WOT, Project Voedselfraude, Nr. WOT-02-005-044.

Acknowledgments: Authors wish to thank Yannick Weesepoel of Wageningen Food Safety Research for his valuable suggestions and Esther van de Vosse for formatting the final text.

Conflicts of Interest: There are no relationship or interest to declare that have inappropriately influenced or biased this study and publication. The funding provider has not influenced the data review nor edited the manuscript.

\section{References}

1. DEFRA. Elliott Review into the Integrity and Assurance of Food Supply Networks-Final Report. A National Food Crime Prevention Framework. Ref: PB14089. Available online: https://www.gov.uk/government/uploads/system/uploads/attachment_ data/file/350726/ elliot-review-final-report-july2014.pdf (accessed on 21 June 2021).

2. Spink, J.; Bedard, B.; Keogh, J.; Moyer, D.C.; Scimeca, J.; Vasan, A. International Survey of Food Fraud and Related Terminology: Preliminary Results and Discussion. J. Food Sci. 2019, 84, 2705-2718. [CrossRef] [PubMed]

3. EFSA Panel on Contaminants in the Food Chain (CONTAM); EFSA Panel on Food Contact Materials, Enzymes, Flavourings and Processing Aids (CEF). Flavourings and Processing Aids (CEF) Scientific Opinion on Melamine in Food and Feed. EFSA J. 2010, 8, 1573. [CrossRef]

4. He, N.X.; Bayen, S. An overview of chemical contaminants and other undesirable chemicals in alcoholic beverages and strategies for analysis. Compr. Rev. Food Sci. Food Saf. 2020, 19, 3916-3950. [CrossRef]

5. Yan, J.; Erasmus, S.W.; Aguilera Toro, M.; Huang, H.; van Ruth, S.M. Food fraud: Assessing fraud vulnerability in the extra virgin olive oil supply chain. Food Control 2020, 111, 107081. [CrossRef]

6. Oliveira, M.M.; Cruz-Tirado, J.P.; Barbin, D.F. Nontargeted Analytical Methods as a Powerful Tool for the Authentication of Spices and Herbs: A Review. Compr. Rev. Food Sci. Food Saf. 2019, 18, 670-689. [CrossRef]

7. McGrath, T.F.; Haughey, S.A.; Patterson, J.; Fauhl-Hassek, C.; Donarski, J.; Alewijn, M.; van Ruth, S.; Elliott, C.T. What are the scientific challenges in moving from targeted to non-targeted methods for food fraud testing and how can they be addressed?Spectroscopy case study. Trends Food Sci. Technol. 2018, 76, 38-55. [CrossRef] 
8. Abasi, S.; Minaei, S.; Jamshidi, B.; Fathi, D. Dedicated non-destructive devices for food quality measurement: A review. Trends Food Sci. Technol. 2018, 78, 197-205. [CrossRef]

9. Petronijević, R.B.; Velebit, B.; Baltić, T. Shedding light on food fraud: Spectrophotometric and spectroscopic methods as a tool against economically motivated adulteration of food. IOP Conf. Ser. Earth Environ. Sci. 2017, 85, 012024. [CrossRef]

10. Xiaobo, Z.; Xiaowei, H.; Povey, M. Non-invasive sensing for food reassurance. Analyst 2016, 141, 1587-1610. [CrossRef]

11. Rateni, G.; Dario, P.; Cavallo, F. Smartphone-Based Food Diagnostic Technologies: A Review. Sensors 2017, 17, 1453. [CrossRef]

12. Kademi, H.I.; Ulusoy, B.H.; Hecer, C. Applications of miniaturized and portable near infrared spectroscopy (NIRS) for inspection and control of meat and meat products. Food Rev. Int. 2018, 35, 201-220. [CrossRef]

13. Beganovic, A.; Hawthorne, L.M.; Bach, K.; Huck, C.W. Critical Review on the Utilization of Handheld and Portable Raman Spectrometry in Meat Science. Foods 2019, 8, 49. [CrossRef] [PubMed]

14. Nascimento, C.F.; Santos, P.M.; Pereira-Filho, E.R.; Rocha, F.R.P. Recent advances on determination of milk adulterants. Food Chem. 2017, 221, 1232-1244. [CrossRef] [PubMed]

15. Naila, A.; Flint, S.H.; Sulaiman, A.Z.; Ajit, A.; Weeds, Z. Classical and novel approaches to the analysis of honey and detection of adulterants. Food Control 2018, 90, 152-165. [CrossRef]

16. dos Santos, C.A.; Lopo, M.; Pascoa, R.N.; Lopes, J.A. A review on the applications of portable near-infrared spectrometers in the agro-food industry. Appl. Spectrosc. 2013, 67, 1215-1233. [CrossRef]

17. Crocombe, R.A. Portable Spectroscopy. Appl. Spectrosc. 2018, 72, 1701-1751. [CrossRef]

18. Sikorska, E.; Khmelinskii, I.; Sikorski, M. Fluorescence spectroscopy and imaging instruments for food quality evaluation. In Evaluation Technologies for Food Quality; Zhong, J., Wang, X., Eds.; Woodhead Publishing: Cambridge, UK, 2019 ; pp. 491-533.

19. Das, A.J.; Wahi, A.; Kothari, I.; Raskar, R. Ultra-portable, wireless smartphone spectrometer for rapid, non-destructive testing of fruit ripeness. Sci. Rep. 2016, 6, 32504. [CrossRef]

20. Rodriguez-Saona, L.; Aykas, D.P.; Borba, K.R.; Urtubia, A. Miniaturization of optical sensors and their potential for highthroughput screening of foods. Curr. Opin. Food Sci. 2020, 31, 136-150. [CrossRef]

21. Limm, W.; Karunathilaka, S.R.; Yakes, B.J.; Mossoba, M.M. A portable mid-infrared spectrometer and a non-targeted chemometric approach for the rapid screening of economically motivated adulteration of milk powder. Int. Dairy J. 2018, 85, 177-183. [CrossRef]

22. Pan, M.; Sun, S.; Zhou, Q.; Chen, J. A Simple and Portable Screening Method for Adulterated Olive Oils Using the Hand-Held FTIR Spectrometer and Chemometrics Tools. J. Food Sci. 2018, 83, 1605-1612. [CrossRef]

23. Gorla, G.; Mestres, M.; Boqué, R.; Riu, J.; Spanu, D.; Giussani, B. ATR-MIR spectroscopy to predict commercial milk major components: A comparison between a handheld and a benchtop instrument. Chemom. Intell. Lab. Syst. 2020, $200,103995$. [CrossRef]

24. Qin, J.; Kim, M.S.; Chao, K.; Dhakal, S.; Cho, B.-K.; Lohumi, S.; Mo, C.; Peng, Y.; Huang, M. Advances in Raman spectroscopy and imaging techniques for quality and safety inspection of horticultural products. Postharvest Biol. Technol. 2019, 149, 101-117. [CrossRef]

25. Markiewicz-Keszycka, M.; Cama-Moncunill, R.; Pietat Casado-Gavalda, M.; Sullivan, C.; Cullen, P.J. Laser-induced breakdown spectroscopy for food authentication. Curr. Opin. Food Sci. 2019, 28, 96-103. [CrossRef]

26. Stuart, M.B.; McGonigle, A.J.S.; Willmott, J.R. Hyperspectral Imaging in Environmental Monitoring: A Review of Recent Developments and Technological Advances in Compact Field Deployable Systems. Sensors 2019, 19, 3071. [CrossRef]

27. Khan, M.J.; Khan, H.S.; Yousaf, A.; Khurshid, K.; Abbas, A. Modern Trends in Hyperspectral Image Analysis: A Review. IEEE Access. 2018, 6, 14118-14129. [CrossRef]

28. Capitani, D.; Sobolev, A.P.; Di Tullio, V.; Mannina, L.; Proietti, N. Portable NMR in food analysis. Chem. Biol. Technol. Agric. 2017, 4. [CrossRef]

29. Shi, H.; Zhang, M.; Adhikari, B. Advances of electronic nose and its application in fresh foods: A review. Crit. Rev. Food Sci. Nutr. 2018, 58, 2700-2710. [CrossRef] [PubMed]

30. Zaukuu, J.L.Z.; Bazar, G.; Gillay, Z.; Kovacs, Z. Emerging trends of advanced sensor based instruments for meat, poultry and fish quality-A review. Crit. Rev. Food Sci. Nutr. 2020, 60, 3443-3460. [CrossRef] [PubMed]

31. Jia, W.; Liang, G.; Jiang, Z.; Wang, J. Advances in Electronic Nose Development for Application to Agricultural Products. Food Anal. Methods 2019, 12, 2226-2240. [CrossRef]

32. Śliwińska, M.; Wiśniewska, P.; Dymerski, T.; Wardencki, W.; Namieśnik, J. Advances in Electronic Noses and Tongues for Food Authenticity Testing. In Advances in Food Authenticity Testing; Downey, G., Ed.; Elsevier: Amsterdam, The Netherlands, 2016; pp. 201-225.

33. Wojnowski, W.; Majchrzak, T.; Dymerski, T.; Gebicki, J.; Namiesnik, J. Electronic noses: Powerful tools in meat quality assessment. Meat Sci. 2017, 131, 119-131. [CrossRef]

34. Di Natale, C.; Dini, F.; Scozzari, A. Non-conventional Electrochemical and Optical Sensor Systems. In Threats to the Quality of Groundwater Resources: Prevention and Control; Scozzari, A., Dotsika, E., Eds.; Springer: Berlin/Heidelberg, Germany, 2016; pp. 279-311.

35. Podrazka, M.; Baczynska, E.; Kundys, M.; Jelen, P.S.; Witkowska Nery, E. Electronic Tongue-A Tool for All Tastes? Biosensors 2017, 8, 3. [CrossRef]

36. Zhang, D.; Liu, Q. Biosensors and bioelectronics on smartphone for portable biochemical detection. Biosens. Bioelectron. 2016, 75, 273-284. [CrossRef] 
37. Nabok, A.; Al-Rubaye, A.G.; Al-Jawdah, A.M.; Tsargorodska, A.; Marty, J.L.; Catanante, G.; Szekacs, A.; Takacs, E. Novel optical biosensing technologies for detection of mycotoxins. Opt. Laser Technol. 2019, 109, 212-221. [CrossRef]

38. Rady, A.; Fischer, J.; Reeves, S.; Logan, B.; Watson, N.J. The Effect of Light Intensity, Sensor Height, and Spectral Pre-Processing Methods when using NIR Spectroscopy to Identify Different Allergen-Containing Powdered Foods. Sensors 2019, $20,230$. [CrossRef]

39. Arsalane, A.; Klilou, A.; Tabyaoui, A.; El Barbri, N.; Rhofir, K. Beef and horse meat discrimination and storage time classification using a portable device based on DSP and PCA method. Int. J. Intell. Enterp. 2017, 4. [CrossRef]

40. Qing, Z.; Ji, B.; Zude, M. Non-destructive analyses of apple quality parameters by means of laser-induced light backscattering imaging. Postharvest. Biol. Technol. 2008, 48, 215-222. [CrossRef]

41. Kim, M.S.; Lefcourt, A.M.; Chen, Y.-R.; Tao, Y. Automated detection of fecal contamination of apples based on multispectral fluorescence image fusion. J. Food Eng. 2005, 71, 85-91. [CrossRef]

42. Makky, M. A Portable Low-cost Non-destructive Ripeness Inspection for Oil Palm FFB. Agric. Agric. Sci. Procedia 2016, 9, 230-240. [CrossRef]

43. Nguyen Do Trong, N.; Erkinbaev, C.; Tsuta, M.; De Baerdemaeker, J.; Nicolaï, B.; Saeys, W. Spatially resolved diffuse reflectance in the visible and near-infrared wavelength range for non-destructive quality assessment of 'Braeburn' apples. Postharvest. Biol. Technol. 2014, 91, 39-48. [CrossRef]

44. Wang, A.; Fu, X.; Xie, L. Application of Visible/Near-Infrared Spectroscopy Combined with Machine Vision Technique to Evaluate the Ripeness of Melons (Cucumis melo L.). Food Anal. Methods 2014, 8, 1403-1412. [CrossRef]

45. Lu, Y.; Li, R.; Lu, R. Structured-illumination reflectance imaging (SIRI) for enhanced detection of fresh bruises in apples. Postharvest. Biol. Technol. 2016, 117, 89-93. [CrossRef]

46. Oliveira, P.C.; Moura, J.P.; Fernandes, L.F.; Amaral, E.M.; Oliveira, A.A. A non-destructive method based on digital image processing for calculate the vigor and the vegetative expression of vines. Comput. Electron. Agric. 2016, 124, 289-294. [CrossRef]

47. Qin, J.; Chao, K.; Kim, M.S. Raman chemical imaging system for food safety and quality inspection. Trans. ASABE 2010, 53, 1873-1882. [CrossRef]

48. Dhakal, S.; Li, Y.; Peng, Y.; Chao, K.; Qin, J.; Guo, L. Prototype instrument development for non-destructive detection of pesticide residue in apple surface using Raman technology. J. Food Eng. 2014, 123, 94-103. [CrossRef]

49. Moscetti, R.; Saeys, W.; Keresztes, J.C.; Goodarzi, M.; Cecchini, M.; Danilo, M.; Massantini, R. Hazelnut Quality Sorting Using High Dynamic Range Short-Wave Infrared Hyperspectral Imaging. Food Bioprocess Technol. 2015, 8, 1593-1604. [CrossRef]

50. Lefcourt, A.M.; Wiederoder, M.S.; Liu, N.; Kim, M.S.; Martin Lo, Y. Development of a portable hyperspectral imaging system for monitoring the efficacy of sanitation procedures in food processing facilities. J. Food Eng. 2013, 117, 59-66. [CrossRef]

51. Wiederoder, M.S.; Liu, N.; Lefcourt, A.M.; Kim, M.S.; Martin Lo, Y. Use of a portable hyperspectral imaging system for monitoring the efficacy of sanitation procedures in produce processing plants. J. Food Eng. 2013, 117, 217-226. [CrossRef]

52. Beck, E.A.; Lefcourt, A.M.; Lo, Y.M.; Kim, M.S. Use of a portable fluorescence imaging device to facilitate cleaning of deli slicers. Food Control 2015, 51, 256-262. [CrossRef]

53. McGonigle, A.J.S.; Wilkes, T.C.; Pering, T.D.; Willmott, J.R.; Cook, J.M.; Mims, F.M.; Parisi, A.V. Smartphone Spectrometers. Sensors 2018, 18, 223. [CrossRef] [PubMed]

54. Utsuzawa, S.; Fukushima, E. Unilateral NMR with a barrel magnet. J. Magn. Reson. 2017, 282, 104-113. [CrossRef]

55. Nakashima, Y. Development of a hand-held magnetic resonance sensor for the nondestructive quantification of fat and lean meat of fresh tuna. J. Food Meas. Charact. 2020, 14, 2947-2955. [CrossRef]

56. Nakashima, Y. Non-Destructive Quantification of Lipid and Water in Fresh Tuna Meat by a Single-Sided Nuclear Magnetic Resonance Scanner. J. Aquat. Food Prod. Technol. 2019, 28, 241-252. [CrossRef]

57. Lei, K.M.; Ha, D.; Song, Y.Q.; Westervelt, R.M.; Martins, R.; Mak, P.I.; Ham, D. Portable NMR with Parallelism. Anal. Chem. 2020, 92, 2112-2120. [CrossRef]

58. Kiani, S.; Minaei, S.; Ghasemi-Varnamkhasti, M. A portable electronic nose as an expert system for aroma-based classification of saffron. Chemom. Intell. Lab. Syst. 2016, 156, 148-156. [CrossRef]

59. Chang, K.H.; Chen, R.L.; Hsieh, B.C.; Chen, P.C.; Hsiao, H.Y.; Nieh, C.H.; Cheng, T.J. A hand-held electronic tongue based on fluorometry for taste assessment of tea. Biosens. Bioelectron. 2010, 26, 1507-1513. [CrossRef]

60. Müller-Maatsch, J.; Bertani, F.R.; Mencattini, A.; Gerardino, A.; Martinelli, E.; Weesepoel, Y.; van Ruth, S. The spectral treasure house of miniaturized instruments for food safety, quality and authenticity applications: A perspective. Trends Food Sci. Technol. 2021. [CrossRef]

61. Capitan-Vallvey, L.F.; Palma, A.J. Recent developments in handheld and portable optosensing-a review. Anal. Chim. Acta 2011, 696, 27-46. [CrossRef]

62. Dian, P.H.; Andueza, D.; Jestin, M.; Prado, I.N.; Prache, S. Comparison of visible and near infrared reflectance spectroscopy to discriminate between pasture-fed and concentrate-fed lamb carcasses. Meat Sci. 2008, 80, 1157-1164. [CrossRef] [PubMed]

63. Perez-Marin, D.; De Pedro Sanz, E.; Guerrero-Ginel, J.E.; Garrido-Varo, A. A feasibility study on the use of near-infrared spectroscopy for prediction of the fatty acid profile in live Iberian pigs and carcasses. Meat Sci. 2009, 83, 627-633. [CrossRef] [PubMed]

64. Prieto, N.; Dugan, M.E.R.; Juárez, M.; López-Campos, Ó.; Zijlstra, R.T.; Aalhus, J.L.; Plaizier, J. Using portable near-infrared spectroscopy to predict pig subcutaneous fat composition and iodine value. Can. J. Anim. Sci. 2018, 98, 221-229. [CrossRef] 
65. Prieto, N.; Juarez, M.; Larsen, I.L.; Lopez-Campos, O.; Zijlstra, R.T.; Aalhus, J.L. Rapid discrimination of enhanced quality pork by visible and near infrared spectroscopy. Meat Sci. 2015, 110, 76-84. [CrossRef]

66. Dixit, Y.; Pham, H.Q.; Realini, C.E.; Agnew, M.P.; Craigie, C.R.; Reis, M.M. Evaluating the performance of a miniaturized NIR spectrophotometer for predicting intramuscular fat in lamb: A comparison with benchtop and hand-held Vis-NIR spectrophotometers. Meat Sci. 2020, 162, 108026. [CrossRef] [PubMed]

67. Perez-Marin, D.; Fearn, T.; Riccioli, C.; De Pedro, E.; Garrido, A. Probabilistic classification models for the in situ authentication of iberian pig carcasses using near infrared spectroscopy. Talanta 2021, 222, 121511. [CrossRef]

68. Piotrowski, C.; Garcia, R.; Garrido-Varo, A.; Perez-Marin, D.; Riccioli, C.; Fearn, T. Short Communication: The potential of portable near infrared spectroscopy for assuring quality and authenticity in the food chain, using Iberian hams as an example. Animal 2019, 13, 3018-3021. [CrossRef] [PubMed]

69. Zamora-Rojas, E.; Perez-Marin, D.; De Pedro-Sanz, E.; Guerrero-Ginel, J.E.; Garrido-Varo, A. In-situ Iberian pig carcass classification using a micro-electro-mechanical system (MEMS)-based near infrared (NIR) spectrometer. Meat Sci. 2012, 90, 636-642. [CrossRef]

70. Horcada, A.; Valera, M.; Juarez, M.; Fernandez-Cabanas, V.M. Authentication of Iberian pork official quality categories using a portable near infrared spectroscopy (NIRS) instrument. Food Chem. 2020, 318, 126471. [CrossRef]

71. Parastar, H.; van Kollenburg, G.; Weesepoel, Y.; van den Doel, A.; Buydens, L.; Jansen, J. Integration of handheld NIR and machine learning to "Measure \& Monitor" chicken meat authenticity. Food Control 2020, 112. [CrossRef]

72. Nolasco Perez, I.M.; Badaro, A.T.; Barbon, S., Jr.; Barbon, A.P.A.; Pollonio, M.A.R.; Barbin, D.F. Classification of Chicken Parts Using a Portable Near-Infrared (NIR) Spectrophotometer and Machine Learning. Appl. Spectrosc. 2018, 72, 1774-1780. [CrossRef]

73. Dumalisile, P.; Manley, M.; Hoffman, L.; Williams, P.J. Discriminating muscle type of selected game species using near infrared (NIR) spectroscopy. Food Control 2020, 110, 106981. [CrossRef]

74. Schmutzler, M.; Beganovic, A.; Böhler, G.; Huck, C.W. Methods for detection of pork adulteration in veal product based on FT-NIR spectroscopy for laboratory, industrial and on-site analysis. Food Control 2015, 57, 258-267. [CrossRef]

75. Silva, L.C.R.; Folli, G.S.; Santos, L.P.; Barros, I.H.A.S.; Oliveira, B.G.; Borghi, F.T.; Santos, F.D.d.; Filgueiras, P.R.; Romão, W. Quantification of beef, pork, and chicken in ground meat using a portable NIR spectrometer. Vib. Spectrosc. 2020, 111, 103158. [CrossRef]

76. Bilge, G.; Velioglu, H.M.; Sezer, B.; Eseller, K.E.; Boyaci, I.H. Identification of meat species by using laser-induced breakdown spectroscopy. Meat Sci. 2016, 119, 118-122. [CrossRef] [PubMed]

77. Casado-Gavalda, M.P.; Dixit, Y.; Geulen, D.; Cama-Moncunill, R.; Cama-Moncunill, X.; Markiewicz-Keszycka, M.; Cullen, P.J.; Sullivan, C. Quantification of copper content with laser induced breakdown spectroscopy as a potential indicator of offal adulteration in beef. Talanta 2017, 169, 123-129. [CrossRef]

78. Andueza, D.; Agabriel, C.; Constant, I.; Lucas, A.; Martin, B. Using visible or near infrared spectroscopy (NIRS) on cheese to authenticate cow feeding regimes. Food Chem. 2013, 141, 209-214. [CrossRef] [PubMed]

79. Uusitalo, S.; Aernouts, B.; Sumen, J.; Eero, H.; Utriainen, M.; Frondelius, L.; Sari, K.; Pastell, M. Comparison of milk analysis performance between NIR laboratory analyser and miniaturised NIR MEMS sensors. In Proceedings of the ICAR Technical Series No 24, Prague, Czech Republic, 17-21 June 2019; ICAR. 111-5.

80. Bogomolov, A.; Belikova, V.; Galyanin, V.; Melenteva, A.; Meyer, H. Reference-free spectroscopic determination of fat and protein in milk in the visible and near infrared region below $1000 \mathrm{~nm}$ using spatially resolved diffuse reflectance fiber probe. Talanta 2017, 167, 563-572. [CrossRef] [PubMed]

81. de Lima, G.F.; Andrade, S.A.C.; da Silva, V.H.; Honorato, F.A. Multivariate Classification of UHT Milk as to the Presence of Lactose Using Benchtop and Portable NIR Spectrometers. Food Anal. Methods 2018, 11, 2699-2706. [CrossRef]

82. Ma, Y.B.; Babu, K.S.; Amamcharla, J.K. Prediction of total protein and intact casein in cheddar cheese using a low-cost handheld short-wave near-infrared spectrometer. LWT Food Sci. Technol. 2019, 109, 319-326. [CrossRef]

83. Liu, N.; Parra, H.A.; Pustjens, A.; Hettinga, K.; Mongondry, P.; van Ruth, S.M. Evaluation of portable near-infrared spectroscopy for organic milk authentication. Talanta 2018, 184, 128-135. [CrossRef]

84. Behkami, S.; Zain, S.M.; Gholami, M.; Khir, M.F.A. Classification of cow milk using artificial neural network developed from the spectral data of single- and three-detector spectrophotometers. Food Chem. 2019, 294, 309-315. [CrossRef]

85. Karunathilaka, S.R.; Yakes, B.J.; He, K.; Chung, J.K.; Mossoba, M. Non-targeted NIR spectroscopy and SIMCA classification for commercial milk powder authentication: A study using eleven potential adulterants. Heliyon 2018, 4, e00806. [CrossRef]

86. Kong, W.W.; Zhang, C.; Liu, F.; Gong, A.P.; He, Y. Irradiation dose detection of irradiated milk powder using visible and near-infrared spectroscopy and chemometrics. J. Dairy Sci. 2013, 96, 4921-4927. [CrossRef]

87. Cheng, Y.; Dong, Y.; Wu, J.; Yang, X.; Bai, H.; Zheng, H.; Ren, D.; Zou, Y.; Li, M. Screening melamine adulterant in milk powder with laser Raman spectrometry. J. Food Compos. Anal. 2010, 23, 199-202. [CrossRef]

88. Sezer, B.; Durna, S.; Bilge, G.; Berkkan, A.; Yetisemiyen, A.; Boyaci, I.H. Identification of milk fraud using laser-induced breakdown spectroscopy (LIBS). Int. Dairy J. 2018, 81, 1-7. [CrossRef]

89. Moncayo, S.; Manzoor, S.; Rosales, J.D.; Anzano, J.; Caceres, J.O. Qualitative and quantitative analysis of milk for the detection of adulteration by Laser Induced Breakdown Spectroscopy (LIBS). Food Chem. 2017, 232, 322-328. [CrossRef] [PubMed]

90. Bilge, G.; Sezer, B.; Eseller, K.E.; Berberoglu, H.; Topcu, A.; Boyaci, I.H. Determination of whey adulteration in milk powder by using laser induced breakdown spectroscopy. Food Chem. 2016, 212, 183-188. [CrossRef] [PubMed] 
91. Grassi, S.; Casiraghi, E.; Alamprese, C. Handheld NIR device: A non-targeted approach to assess authenticity of fish fillets and patties. Food Chem. 2018, 243, 382-388. [CrossRef]

92. O'Brien, N.; Hulse, C.A.; Pfeifer, F.; Siesler, H.W. Near Infrared Spectroscopic Authentication of Seafood. J. Near Infrared Spectrosc. 2013, 21, 299-305. [CrossRef]

93. He, H.-J.; Wu, D.; Sun, D.-W. Non-destructive and rapid analysis of moisture distribution in farmed Atlantic salmon (Salmo salar) fillets using visible and near-infrared hyperspectral imaging. Innov. Food Sci. Emerg. Technol. 2013, 18, 237-245. [CrossRef]

94. Coronel Reyes, J.; Ramirez-Morales, I. Determination of egg storage time at room temperature using a low-cost NIR spectrometer and machine learning techniques. Comput. Electron. Agric. 2018, 145, 1-10. [CrossRef]

95. Kaszab, T.; Bodor, Z.; Kovacs, Z.; Benedek, C. Classification models of hungarian honey samples based on analytical and physical characteristics. Hung. Agric. Eng. 2017, 32, 22-28. [CrossRef]

96. Lastra-Mejías, M.; Izquierdo, M.; González-Flores, E.; Cancilla, J.C.; Izquierdo, J.G.; Torrecilla, J.S. Honey exposed to laserinduced breakdown spectroscopy for chaos-based botanical classification and fraud assessment. Chemom. Intell. Lab. Syst. 2020, 199, 103939. [CrossRef]

97. Stefas, D.; Gyftokostas, N.; Couris, S. Laser induced breakdown spectroscopy for elemental analysis and discrimination of honey samples. Spectrochim. Acta Part B 2020, 172, 105969. [CrossRef]

98. Vincent, J.; Wang, H.; Nibouche, O.; Maguire, P. Differentiation of Apple Varieties and Investigation of Organic Status Using Portable Visible Range Reflectance Spectroscopy. Sensors 2018, 18, 1708. [CrossRef]

99. Dong, Y.; Liu, X.; Mei, L.; Feng, C.; Yan, C.; He, S. LED-induced fluorescence system for tea classification and quality assessment. J. Food Eng. 2014, 137, 95-100. [CrossRef]

100. You, H.; Kim, Y.; Lee, J.-H.; Jang, B.-J.; Choi, S. Food Powder Classification Using a Portable Visible-Near-Infrared Spectrometer. J. Electromagn. Eng. Sci. 2017, 17, 186-190. [CrossRef]

101. Toivonen, P.; Batista, A.; Lannard, B. Development of a predictive model for 'Lapins' sweet cherry dry matter content using a visible/near infrared spectrometer and its potential application to other cultivars. Can. J. Plant Sci. 2017, 97, 1030-1035. [CrossRef]

102. Davey, M.W.; Saeys, W.; Hof, E.; Ramon, H.; Swennen, R.L.; Keulemans, J. Application of Visible and Near-Infrared Reflectance Spectroscopy (Vis/NIRS) to Determine Carotenoid Contents in Banana (Musa spp.) Fruit Pulp. J. Agric. Food Chem. 2009, 57, 1742-1751. [CrossRef] [PubMed]

103. Ikeogu, U.N.; Davrieux, F.; Dufour, D.; Ceballos, H.; Egesi, C.N.; Jannink, J.L. Rapid analyses of dry matter content and carotenoids in fresh cassava roots using a portable visible and near infrared spectrometer (Vis/NIRS). PLoS ONE 2017, 12, e0188918. [CrossRef]

104. Szuvandzsiev, P.; Helyes, L.; Lugasi, A.; Szántó, C.; Baranowski, P.; Pék, Z. Estimation of antioxidant components of tomato using VIS-NIR reflectance data by handheld portable spectrometer. Int. Agrophys. 2014, 28. [CrossRef]

105. Ndlovu, P.F.; Magwaza, L.S.; Tesfay, S.Z.; Mphahlele, R.R. Rapid visible-near infrared (Vis-NIR) spectroscopic detection and quantification of unripe banana flour adulteration with wheat flour. J. Food Sci. Technol. 2019, 56, 5484-5491. [CrossRef]

106. Rukundo, I.R.; Danao, M.C. Identifying Turmeric Powder by Source and Metanil Yellow Adulteration Levels Using Near-Infrared Spectra and PCA-SIMCA Modeling. J. Food Prot. 2020, 83, 968-974. [CrossRef]

107. Mat Nawi, N.; Chen, G.; Jensen, T. Application of visible and shortwave near infrared spectrometer to predict sugarcane quality from different sample forms. In Sensing Technologies for Biomaterial, Food, and Agriculture; Kondo, N., Ed.; SPIE-International Society for Optics and Photonics: Bellingham, WA, USA, 2013; p. 88810A.

108. Steidle Neto, A.J.; Toledo, J.V.; Zolnier, S.; Lopes, D.d.C.; Pires, C.V.; Silva, T.G.F.d. Prediction of mineral contents in sugarcane cultivated under saline conditions based on stalk scanning by Vis/NIR spectral reflectance. Biosyst. Eng. 2017, 156, 17-26. [CrossRef]

109. Jamshidi, B.; Mohajerani, E.; Jamshidi, J. Developing a Vis/NIR spectroscopic system for fast and non-destructive pesticide residue monitoring in agricultural product. Measurement 2016, 89, 1-6. [CrossRef]

110. Guidetti, R.; Beghi, R.; Bodria, L. Evaluation of grape quality parameters by a simple VISNIR system. Trans. ASABE 2010, 53, 477-484. [CrossRef]

111. Wang, Y.J.; Li, T.H.; Li, L.Q.; Ning, J.M.; Zhang, Z.Z. Micro-NIR spectrometer for quality assessment of tea: Comparison of local and global models. Spectrochim. Acta Part A 2020, 237, 118403. [CrossRef]

112. Plans, M.; Simó, J.; Casañas, F.; Sabaté, J.; Rodriguez-Saona, L. Characterization of common beans (Phaseolus vulgaris L.) by infrared spectroscopy: Comparison of MIR, FT-NIR and dispersive NIR using portable and benchtop instruments. Food Res. Int. 2013, 54, 1643-1651. [CrossRef]

113. Pérez-Marín, D.; Paz, P.; Guerrero, J.-E.; Garrido-Varo, A.; Sánchez, M.-T. Miniature handheld NIR sensor for the on-site non-destructive assessment of post-harvest quality and refrigerated storage behavior in plums. J. Food Eng. 2010, 99, 294-302. [CrossRef]

114. Pan, L.; Lu, R.; Zhu, Q.; McGrath, J.M.; Tu, K. Measurement of moisture, soluble solids, sucrose content and mechanical properties in sugar beet using portable visible and near-infrared spectroscopy. Postharvest. Biol. Technol. 2015, 102, 42-50. [CrossRef]

115. Yu, H.; Liu, H.; Wang, Q.; van Ruth, S. Evaluation of portable and benchtop NIR for classification of high oleic acid peanuts and fatty acid quantitation. LWT Food Sci. Technol. 2020, 128, 109398. [CrossRef]

116. Yan, H.; Xu, Y.C.; Siesler, H.W.; Han, B.X.; Zhang, G.Z. Hand-Held Near-Infrared Spectroscopy for Authentication of Fengdous and Quantitative Analysis of Mulberry Fruits. Front. Plant Sci. 2019, 10, 1548. [CrossRef] [PubMed] 
117. Correia, R.M.; Tosato, F.; Domingos, E.; Rodrigues, R.R.T.; Aquino, L.F.M.; Filgueiras, P.R.; Lacerda, V., Jr.; Romao, W. Portable near infrared spectroscopy applied to quality control of Brazilian coffee. Talanta 2018, 176, 59-68. [CrossRef] [PubMed]

118. Oliveira, M.M.; Cruz-Tirado, J.P.; Roque, J.V.; Teófilo, R.F.; Barbin, D.F. Portable near-infrared spectroscopy for rapid authentication of adulterated paprika powder. J. Food Compos. Anal. 2020, 87, 103403. [CrossRef]

119. Kar, S.; Tudu, B.; Bag, A.K.; Bandyopadhyay, R. Application of Near-Infrared Spectroscopy for the Detection of Metanil Yellow in Turmeric Powder. Food Anal. Methods 2017, 11, 1291-1302. [CrossRef]

120. McVey, C.; McGrath, T.F.; Haughey, S.A.; Elliott, C.T. A rapid food chain approach for authenticity screening: The development, validation and transferability of a chemometric model using two handheld near infrared spectroscopy (NIRS) devices. Talanta 2021, 222, 121533. [CrossRef] [PubMed]

121. Haughey, S.A.; Galvin-King, P.; Malechaux, A.; Elliott, C.T. The Use of Handheld near Infrared Reflectance Spectroscopy for the Proximate Analysis of Poultry Feed and to Detect Melamine Adulteration of Soya Bean Meal. NIR News 2015, 26, 4-7. [CrossRef]

122. Sanchez, M.T.; Torres, I.; de la Haba, M.J.; Chamorro, A.; Garrido-Varo, A.; Perez-Marin, D. Rapid, simultaneous, and in situ authentication and quality assessment of intact bell peppers using near-infrared spectroscopy technology. J. Sci. Food Agric. 2019, 99, 1613-1622. [CrossRef]

123. Castrignanò, A.; Buttafuoco, G.; Malegori, C.; Genorini, E.; Iorio, R.; Stipic, M.; Girone, G.; Venezia, A. Assessing the Feasibility of a Miniaturized Near-Infrared Spectrometer in Determining Quality Attributes of San Marzano Tomato. Food Anal. Methods 2019, 12, 1497-1510. [CrossRef]

124. Song, W.; Wang, H.; Maguire, P.; Nibouche, O. Differentiation of organic and non-organic apples using near infrared reflectance spectroscopy-A pattern recognition approach. In Proceedings of the 2016 IEEE SENSORS, Orlando, FL, USA, 30 October-3 November 2016; pp. 1-3.

125. Rotbart, N.; Schmilovitch, Z.; Cohen, Y.; Alchanatis, V.; Erel, R.; Ignat, T.; Shenderey, C.; Dag, A.; Yermiyahu, U. Estimating olive leaf nitrogen concentration using visible and near-infrared spectral reflectance. Biosyst. Eng. 2013, 114, 426-434. [CrossRef]

126. Perez-Marin, D.; Torres, I.; Entrenas, J.A.; Vega, M.; Sanchez, M.T. Pre-harvest screening on-vine of spinach quality and safety using NIRS technology. Spectrochim. Acta Part A 2019, 207, 242-250. [CrossRef]

127. Teye, E.; Amuah, C.L.Y.; McGrath, T.; Elliott, C. Innovative and rapid analysis for rice authenticity using hand-held NIR spectrometry and chemometrics. Spectrochim. Acta Part A 2019, 217, 147-154. [CrossRef]

128. Zhu, G.; Tian, C. Determining sugar content and firmness of 'Fuji' apples by using portable near-infrared spectrometer and diffuse transmittance spectroscopy. J. Food Process Eng. 2018, 41, e12810. [CrossRef]

129. Manfredi, M.; Robotti, E.; Quasso, F.; Mazzucco, E.; Calabrese, G.; Marengo, E. Fast classification of hazelnut cultivars through portable infrared spectroscopy and chemometrics. Spectrochim. Acta Part A 2018, 189, 427-435. [CrossRef]

130. Guzman, E.; Baeten, V.; Pierna, J.A.; Garcia-Mesa, J.A. A portable Raman sensor for the rapid discrimination of olives according to fruit quality. Talanta 2012, 93, 94-98. [CrossRef]

131. Krimmer, M.; Farber, C.; Kurouski, D. Rapid and Noninvasive Typing and Assessment of Nutrient Content of Maize Kernels Using a Handheld Raman Spectrometer. ACS Omega 2019, 4, 16330-16335. [CrossRef] [PubMed]

132. Vargas Jentzsch, P.; Torrico-Vallejos, S.; Mendieta-Brito, S.; Ramos, L.A.; Ciobotă, V. Detection of counterfeit stevia products using a handheld Raman spectrometer. Vib. Spectrosc. 2016, 83, 126-131. [CrossRef]

133. Perez-Rodriguez, M.; Dirchwolf, P.M.; Silva, T.V.; Villafane, R.N.; Neto, J.A.G.; Pellerano, R.G.; Ferreira, E.C. Brown rice authenticity evaluation by spark discharge-laser-induced breakdown spectroscopy. Food Chem. 2019, 297, 124960. [CrossRef]

134. Yang, P.; Zhu, Y.; Yang, X.; Li, J.; Tang, S.; Hao, Z.; Guo, L.; Li, X.; Zeng, X.; Lu, Y. Evaluation of sample preparation methods for rice geographic origin classification using laser-induced breakdown spectroscopy. J. Cereal Sci. 2018, 80, 111-118. [CrossRef]

135. Sezer, B.; Apaydin, H.; Bilge, G.; Boyaci, I.H. Coffee arabica adulteration: Detection of wheat, corn and chickpea. Food Chem. 2018, 264, 142-148. [CrossRef] [PubMed]

136. Su, W.-H.; Sun, D.-W. Evaluation of spectral imaging for inspection of adulterants in terms of common wheat flour, cassava flour and corn flour in organic Avatar wheat (Triticum spp.) flour. J. Food Eng. 2017, 200, 59-69. [CrossRef]

137. Henn, R.; Schwab, A.; Huck, C.W. Evaluation of benchtop versus portable near-infrared spectroscopic method combined with multivariate approaches for the fast and simultaneous quantitative analysis of main sugars in syrup formulations. Food Control 2016, 68, 97-104. [CrossRef]

138. Jahani, R.; Yazdanpanah, H.; van Ruth, S.M.; Kobarfard, F.; Alewijn, M.; Mahboubi, A.; Faizi, M.; Shojaee AliAbadi, M.H.; Salamzadeh, J. Novel Application of Near-infrared Spectroscopy and Chemometrics Approach for Detection of Lime Juice Adulteration. Iran. J. Pharm. Res. 2020, 19, 34-44. [CrossRef] [PubMed]

139. Karunathilaka, S.R.; Yakes, B.J.; Farris, S.; Michael, T.J.; He, K.; Chung, J.K.; Shah, R.; Mossoba, M.M. Quantitation of Saccharin and Cyclamate in Tabletop Formulations by Portable Raman and NIR Spectrometers in Combination with Partial Least Squares Regression. Food Anal. Methods 2017, 11, 969-979. [CrossRef]

140. Basri, K.N.; Hussain, M.N.; Bakar, J.; Sharif, Z.; Khir, M.F.A.; Zoolfakar, A.S. Classification and quantification of palm oil adulteration via portable NIR spectroscopy. Spectrochim. Acta Part A 2017, 173, 335-342. [CrossRef]

141. Teye, E.; Elliott, C.; Sam-Amoah, L.K.; Mingle, C. Rapid and nondestructive fraud detection of palm oil adulteration with Sudan dyes using portable NIR spectroscopic techniques. Food Addit. Contam. Part A 2019, 36, 1589-1596. [CrossRef]

142. Yan, J.; Stuijvenberg, L.; Ruth, S.M. Handheld Near-Infrared Spectroscopy for Distinction of Extra Virgin Olive Oil from Other Olive Oil Grades Substantiated by Compositional Data. Eur. J. Lipid Sci. Technol. 2019, 121. [CrossRef] 
143. Yang, M.; Chen, Q.; Kutsanedzie, F.Y.H.; Yang, X.; Guo, Z.; Ouyang, Q. Portable spectroscopy system determination of acid value in peanut oil based on variables selection algorithms. Measurement 2017, 103, 179-185. [CrossRef]

144. Kaufmann, K.C.; Favero, F.F.; de Vasconcelos, M.A.M.; Godoy, H.T.; Sampaio, K.A.; Barbin, D.F. Portable NIR Spectrometer for Prediction of Palm Oil Acidity. J. Food Sci. 2019, 84, 406-411. [CrossRef]

145. Picouet, P.A.; Gou, P.; Hyypiö, R.; Castellari, M. Implementation of NIR technology for at-line rapid detection of sunflower oil adulterated with mineral oil. J. Food Eng. 2018, 230, 18-27. [CrossRef]

146. Giovenzana, V.; Beghi, R.; Guidetti, R. Rapid evaluation of craft beer quality during fermentation process by vis/NIR spectroscopy. J. Food Eng. 2014, 142, 80-86. [CrossRef]

147. Allendorf, M.; Subramanian, A.; Rodriguez-Saona, L. Application of a Handheld Portable Mid-Infrared Sensor for Monitoring Oil Oxidative Stability. J. Am. Oil Chem. Soc. 2011, 89, 79-88. [CrossRef]

148. Maurer, N.E.; Hatta-Sakoda, B.; Pascual-Chagman, G.; Rodriguez-Saona, L.E. Characterization and authentication of a novel vegetable source of omega-3 fatty acids, sacha inchi (Plukenetia volubilis L.) oil. Food Chem. 2012, 134, 1173-1180. [CrossRef] [PubMed]

149. Bellou, E.; Gyftokostas, N.; Stefas, D.; Gazeli, O.; Couris, S. Laser-induced breakdown spectroscopy assisted by machine learning for olive oils classification: The effect of the experimental parameters. Spectrochim. Acta Part B 2020, 163, 105746. [CrossRef]

150. Moncayo, S.; Rosales, J.D.; Izquierdo-Hornillos, R.; Anzano, J.; Caceres, J.O. Classification of red wine based on its protected designation of origin (PDO) using Laser-induced Breakdown Spectroscopy (LIBS). Talanta 2016, 158, 185-191. [CrossRef] [PubMed]

151. Tian, Y.; Yan, C.; Zhang, T.; Tang, H.; Li, H.; Yu, J.; Bernard, J.; Chen, L.; Martin, S.; Delepine-Gilon, N.; et al. Classification of wines according to their production regions with the contained trace elements using laser-induced breakdown spectroscopy. Spectrochim. Acta Part B 2017, 135, 91-101. [CrossRef]

152. Vargas Jentzsch, P.; Ciobotă, V. Raman spectroscopy as an analytical tool for analysis of vegetable and essential oils. Flavour Fragr. J. 2014, 29, 287-295. [CrossRef]

153. Zou, M.Q.; Zhang, X.F.; Qi, X.H.; Ma, H.L.; Dong, Y.; Liu, C.W.; Guo, X.; Wang, H. Rapid authentication of olive oil adulteration by Raman spectrometry. J. Agric. Food Chem. 2009, 57, 6001-6006. [CrossRef]

154. Van Ruth, S.M.; Nillesen, O. Which company characteristics make a food business at risk for food fraud. Foods $2021,10,842$. [CrossRef]

155. Müller-Maatsch, J.; Alewijn, M.; Wijtten, M.; Weesepoel, Y. Detecting fraudulent additions in skimmed milk powder using a portable, hyphenated, optical multi-sensor approach in combination with one-class classification. Food Control 2020, 121, 107744. [CrossRef]

156. Weesepoel, Y.; Alewijn, M.; Wijtten, M.; Müller-Maatsch, J. Detecting food fraud in extra virgin olive oil using a prototype portable hyphenated photonics sensor. J. AOAC Int. 2020. [CrossRef] [PubMed]

157. Chao, K.; Nou, X.; Liu, Y.; Kim, S.; Chan, D.E.; Yang, C.-C.; Patel, J.; Sharma, M. Detection of fecal/ingesta contaminants on poultry processing equipment surfaces by visible and near-infrared reflectance spectroscopy. Appl. Eng. Agric. 2008, 23, 49-55. [CrossRef]

158. Ait-Kaddour, A.; Boubellouta, T.; Chevallier, I. Development of a portable spectrofluorimeter for measuring the microbial spoilage of minced beef. Meat Sci. 2011, 88, 675-681. [CrossRef] [PubMed]

159. Savoia, S.; Albera, A.; Brugiapaglia, A.; Di Stasio, L.; Ferragina, A.; Cecchinato, A.; Bittante, G. Prediction of meat quality traits in the abattoir using portable and hand-held near-infrared spectrometers. Meat Sci. 2019, 161, 108017. [CrossRef]

160. Kartakoullis, A.; Comaposada, J.; Cruz-Carrion, A.; Serra, X.; Gou, P. Feasibility study of smartphone-based near-infrared spectroscopy (NIRS) for salted minced meat composition diagnostics at different temperatures. Food Chem. 2019, 278, 314-321. [CrossRef]

161. Collell, C.; Gou, P.; Arnau, J.; Muñoz, I.; Comaposada, J. NIR technology for on-line determination of superficial a(2) and moisture content during the drying process of fermented sausages. Food Chem. 2012, 135, 1750-1755. [CrossRef] [PubMed]

162. Prado, N.; Fernández-Ibáñez, V.; González, P. On-site NIR spectroscopy to control the shelf life of pork meat. Food Anal. Method 2011, 4, 582-589. [CrossRef]

163. Kucha, C.; Ngadi, M.O. Rapid assessment of pork freshness using miniaturized NIR spectroscopy. J. Food Meas. Charact. 2020, 14, 1105-1115. [CrossRef]

164. Jaafreh, S.; Breuch, R.; Guenther, K.; Kreyenschmidt, J. Rapid poultry spoilage evaluation using portable fiber-optic raman spectrometer. Food Anal. Method 2018, 11, 2320-2328. [CrossRef]

165. Liu, Y.; Windham, W.R.; Lawrence, K.C.; Park, B. Simple algorithms for the classification of visible/near-infrared and hyperspectral imaging spectra of chicken skins, feces, and fecal contaminated skins. Appl. Spectrosc. 2003, 57, 1609-1612. [CrossRef]

166. Karoui, R.; Dufour, E. Development of a portable spectrofluorometer for measuring the quality of cheese. Dairy Sci. Technol. 2008, 88, 477-494. [CrossRef]

167. Wiedemair, V.; Langore, D.; Garsleitner, R. Investigations into the performance of a novel pocket-sized near-infrared spectrometer for cheese analysis. Molecules 2019, 24, 428. [CrossRef]

168. Riu, J.; Gorla, G.; Chakif, C.; Boqué, R.; Giussani, B. Rapid analysis of milk using low-cost pocket-size NIR spectrometers and multivariate analysis. Foods 2020, 9, 1090. [CrossRef] 
169. Temiz, T.; Sezer, B.; Berkkan, A.; Tamer, U. Assessment of laser induced breakdown spectroscopy as a tool for analysis of butter adulterations. J. Food Compos. Anal. 2017, 67, 48-54. [CrossRef]

170. Shimamoto, J.; Hiratsuka, S.; Hasegawa, K. Rapid non-destructive determination of fat content in frozen skipjack using a portable near infrared spectrophotometer. Fisheries Sci. 2003, 69, 856-860. [CrossRef]

171. Yu, X.; Tang, L.; Wu, X.; Lu, H. Nondestructive freshness discriminating of shrimp using visible/near-infrared hyperspectral imaging technique and deep learning algorithm. Food Anal. Method 2018, 11, 768-780. [CrossRef]

172. Castrica, M.; Panseri, S.; Siletti, E. Evaluation of smart portable device for food diagnostics: A preliminary study on cape hake fillets (M. capensis and M. paradoxus). J. Chem. 2019, 2019, 2904724. [CrossRef]

173. Fu, X.; He, X.; Xu, H.; Ying, Y. Nondestructive and rapid assessment of intact tomato freshness and lycopene content based on a miniaturized raman spectroscopy system and colorimetry. Food Anal. Method 2016, 9, 2501-2508. [CrossRef]

174. Smeesters, L.; Meulebroeck, W.; Raeymaekers, S.; Thienpont, H. Optical detection of aflatoxins in maize using one- and twophoton induced fluorescence spectroscopy. Food Control 2015, 51, 408-416. [CrossRef]

175. Mat Nawi, N.; Chen, G.; Jensen, T.; Mehdizadeh, S.A. Prediction and classification of sugar content of sugarcane based on skin scanning using visible and shortwave near infrared. Biosyst. Eng. 2013, 115, 154-161. [CrossRef]

176. Saranwong, S.; Sornsrivichai, J.; Kawano, S. Performance of a portable near infrared instrument for Brix value determination of intact mango fruit. J. Near Infrared Spectrosc. 2003, 11, 175-181. [CrossRef]

177. Santos Neto, J.P.; Leite, G.W.; Oliveira, G.D.; Cunha Júnior, L.C.; Gratão, P.L.; Morais, C.D.; Teixeira, G.H. Cold storage of 'Palmer' mangoes sorted based on dry matter content using portable near infrared (VIS-NIR) spectrometer. J. Food Process. Preserv. 2018, 42, e13644. [CrossRef]

178. dos Santos Neto, J.P.; de Assis, M.W.D.; Casagrande, I.P.; Cunha Júnior, L.C.; de Almeida Teixeira, G.H. Determination of 'Palmer' mango maturity indices using portable near infrared (VIS-NIR) spectrometer. Postharvest Biol. Technol. 2017, 130, 75-80. [CrossRef]

179. Li, P.; Li, S.; Du, G.; Jiang, L.; Liu, X.; Ding, S.; Shan, Y. A simple and nondestructive approach for the analysis of soluble solid content in citrus by using portable visible to near-infrared spectroscopy. Food Sci. Nutr. 2020, 8, 2543-2552. [CrossRef] [PubMed]

180. Beghi, R.; Spinardi, A.; Bodria, L.; Mignani, I.; Guidetti, R. Apples Nutraceutic Properties Evaluation Through a Visible and Near-Infrared Portable System. Food Bioprocess Technol. 2012, 6, 2547-2554. [CrossRef]

181. Cayuela, J.A.; Weiland, C. Intact orange quality prediction with two portable NIR spectrometers. Postharvest Biol. Technol. 2010, 58, 113-120. [CrossRef]

182. Li, M.; Qian, Z.; Shi, B.; Medlicott, J.; East, A. Evaluating the performance of a consumer scale SCiO ${ }^{\mathrm{TM}}$ molecular sensor to predict quality of horticultural products. Postharvest Biol. Technol. 2018, 145, 183-192. [CrossRef]

183. Kaur, H.; Künnemeyer, R.; McGlone, A. Comparison of hand-held near infrared spectrophotometers for fruit dry matter assessment. J. Near Infrared Spectrosc. 2017, 25, 267-277. [CrossRef]

184. Wiedemair, V.; Huck, C.W. Evaluation of the performance of three hand-held near-infrared spectrometer through investigation of total antioxidant capacity in gluten-free grains. Talanta 2018, 189, 233-240. [CrossRef] [PubMed]

185. León, L.; Gracia, A. Non-destructive assessment of olive fruit ripening by portable near infrared spectroscopy. Grasas $Y$ Aceites 2011, 62, 268-274. [CrossRef]

186. Fernandez-Espinosa, A.J. Combining PLS regression with portable NIR spectroscopy to on-line monitor quality parameters in intact olives for determining optimal harvesting time. Talanta 2016, 148, 216-228. [CrossRef]

187. Cirilli, M.; Bellincontro, A.; Urbani, S.; Servili, M.; Esposto, S.; Mencarelli, F.; Muleo, R. On-field monitoring of fruit ripening evolution and quality parameters in olive mutants using a portable NIR-AOTF device. Food Chem. 2016, 199, 96-104. [CrossRef]

188. Sánchez, M.-T.; De la Haba, M.-J.; Pérez-Marín, D. Internal and external quality assessment of mandarins on-tree and at harvest using a portable NIR spectrophotometer. Comput. Electron. Agric. 2013, 92, 66-74. [CrossRef]

189. Blakey, R.J. Evaluation of avocado fruit maturity with a portable near-infrared spectrometer. Postharvest Biol. Technol. 2016, 121, 101-105. [CrossRef]

190. Sánchez, M.-T.; De la Haba, M.-J.; Guerrero, J.-E.; Garrido-Varo, A.; Pérez-Marín, D. Testing of a local approach for the prediction of quality parameters in intact nectarines using a portable NIRS instrument. Postharvest Biol. Technol. 2011, 60, 130-135. [CrossRef]

191. Sánchez, M.-T.; De la Haba, M.J.; Benítez-López, M.; Fernández-Novales, J.; Garrido-Varo, A.; Pérez-Marín, D. Non-destructive characterization and quality control of intact strawberries based on NIR spectral data. J. Food Eng. 2012, 110, 102-108. [CrossRef]

192. Torres, I.; Pérez-Marín, D.; De la Haba, M.-J.; Sánchez, M.-T. Developing universal models for the prediction of physical quality in citrus fruits analysed on-tree using portable NIRS sensors. Biosyst. Eng. 2017, 153, 140-148. [CrossRef]

193. Baca-Bocanegra, B.; Hernandez-Hierro, J.M.; Nogales-Bueno, J.; Heredia, F.J. Feasibility study on the use of a portable micro near infrared spectroscopy device for the "in vineyard" screening of extractable polyphenols in red grape skins. Talanta 2019, 192, 353-359. [CrossRef] [PubMed]

194. Marques, E.J.; de Freitas, S.T.; Pimentel, M.F.; Pasquini, C. Rapid and non-destructive determination of quality parameters in the 'Tommy Atkins' mango using a novel handheld near infrared spectrometer. Food Chem. 2016, 197 Pt B, 1207-1214. [CrossRef]

195. Liu, Y.; Sun, X.; Zhang, H.; Aiguo, O. Nondestructive measurement of internal quality of Nanfeng mandarin fruit by charge coupled device near infrared spectroscopy. Comput. Electron. Agric. 2010, 71, S10-S14. [CrossRef]

196. Suhandy, D.; Yulia, M.; Kuncoro, S.; Rhinaldo, W.; Kondo, N.; Ogawa, Y. The Measurement of Soluble Solids Content in Snake Fruit (Salacca Edulis Reinw) cv. Pondoh Using A Portable Spectrometer. IFAC Proc. Vol. 2010, 43, 235-240. [CrossRef] 
197. Jie, D.; Xie, L.; Fu, X.; Rao, X.; Ying, Y. Variable selection for partial least squares analysis of solutble solids content in wtermelon using near-infrared diffuse transmission technicque. J. Food Eng. 2013, 118, 387-392. [CrossRef]

198. Jie, D.; Xie, L.; Rao, X.; Ying, Y. Using visible and near infrared diffuse transmittance technique to predict soluble solids content of wtermelon in an on-line detection system. Postharvest Biol. Technol. 2014, 90, 1-6. [CrossRef]

199. Jie, D.; Zhou, W.; Wei, X. Nondestructive detection of maturity of wtermelon by spectral characteristic using NIR diffuse transmittance technique. Sci. Hortic. 2019, 257, 108718. [CrossRef]

200. Beghi, R.; Giovenzana, V.; Civelli, R.; Malegori, C.; Buratti, S.; Guidetti, R. Setting-up of a simplified handheld optical device for decay detection in fresh-cut Valerianella locusta L. J. Food Eng. 2014, 127, 10-15. [CrossRef]

201. Huang, Y.; Lu, R.; Chen, K. Assessment of tomato soluble solids content and pH by spatially-resolved and conventional Vis/NIR spectroscopy. J. Food Eng. 2018, 236, 19-28. [CrossRef]

202. Esquerre, C.A.; Achata, E.M.; García-Vaquero, M.; Zhang, Z.; Tiwari, B.K.; O’Donnell, C.P. Use of an NIR MEMS spectrophotometer and visible/NIR hyperspectral imaging systems to predict quality parameters of treated ground peppercorns. LWT 2020, 131, 109761. [CrossRef]

203. Kiani, S.; van Ruth, S.M.; van Raamsdonk, L.W.D.; Minaei, S. Hyperspectral imaging as a novel system for the authentication of spices: A nutmeg case study. LWT 2019, 104, 61-69. [CrossRef]

204. Qin, J.; Burks, T.F.; Kim, M.S.; Chao, K.; Ritenour, M.A. Citrus canker detection using hyperspectral reflectance imaging and PCA-based image classification method. Sens. Instrum. Food Qual. Saf. 2008, 2, 168-177. [CrossRef]

205. Pathange, L.P.; Mallikarjunan, P.; Marini, R.P.; O'Keefe, S.; Vaughan, D. Non-destructive evaluation of apple maturity using an electronic nose system. J. Food Eng. 2006, 77, 1018-1023. [CrossRef] 